\title{
Geochemistry of pyroxenitic and hornblenditic xenoliths in alkaline lamprophyres from the Spanish Central System
}

\author{
David Orejana $^{\mathrm{a}, *}$, Carlos Villaseca ${ }^{\mathrm{a}}$, Bruce A. Paterson ${ }^{\mathrm{b}}$ \\ ${ }^{a}$ Departamento de Petrología y Geoquimica, Facultad de Ciencias Geológicas, Universidad Complutense, Madrid 28040, Spain \\ ${ }^{\mathrm{b}}$ Department of Earth Sciences, University of Bristol, Bristol BS8 IRJ, United Kingdom
}

\begin{abstract}
The alkaline lamprophyres and diabases of the Spanish Central System carry a heterogeneous suite of xenoliths which includes scarce pyroxenitic and hornblenditic types that can be divided in two groups: (a) pyroxenite xenoliths, including spinel clinopyroxenites and spinel websterites with granoblastic textures, and (b) hornblende-bearing clinopyroxenites and hornblendites (here after called hornblenditic xenoliths) characterised by the presence of Ti-rich kaersutitic amphibole and magmatic textures. Both groups of xenoliths can be assigned to the Al-augite series of Wilshire and Shervais (1975) [Wilshire, H.G., Shervais, J.W., 1975. Al-augite and Cr-diopside ultramafic xenoliths in basaltic rocks from western United States. Phys. Chem. Earth 9, 257-272] with Al-rich and Cr-poor mafic phases. Clinopyroxenes show a very similar trace element composition in all of the ultramafic xenoliths, characterised by convex-upward chondrite-normalised REE patterns and low contents of incompatible elements such as $\mathrm{Rb}, \mathrm{Ba}$, Th and $\mathrm{Nb}$. Kaersutite in the amphibole-bearing xenoliths shows a similar convex-upward REE pattern as clinopyroxene. Whole-rock and mineral geochemistry support an origin as cumulates from alkaline to subalkaline melts for most of the pyroxenites and hornblendites that have been studied. The $\mathrm{Sr}-\mathrm{Nd}$ isotope ratios of pyroxenite xenoliths display two extreme compositional poles: one clinopyroxenite plots in the OIB field towards depleted values $\left({ }^{87} \mathrm{Sr} /{ }^{86} \mathrm{Sr}=0.7028\right.$ and $\left.\varepsilon \mathrm{Nd}=6.2\right)$, whereas the other pyroxenites plot in enriched lithospheric fields (0.705 to 0.706 and -2.8 to -3.4 , respectively), which implies that different magmas have been involved in their genesis. The hornblenditic xenolith suite has a very homogeneous isotopic composition, close to the isotopically depleted values of high $\varepsilon \mathrm{Nd}$ and low ${ }^{87} \mathrm{Sr} /{ }^{86} \mathrm{Sr}$ ratios of one of the pyroxenite xenoliths. Some of these ultramafic xenoliths fall within the isotopic compositional range of their host alkaline dykes, which also define a bipolar compositional field, suggesting that most of them are cogenetic with the lamprophyres. P-T estimates yield temperatures in the range of $970-1080{ }^{\circ} \mathrm{C}$ and pressures mainly from 0.9 to $1.2 \mathrm{GPa}$ for pyroxenites, whilst hornblenditic xenoliths give lower (and probably underestimated) pressures (0.7-0.9 GPa). This pressure range is in agreement with pyroxenites being formed by an underplating event at the upper mantle-lower crust boundary, whereas pressure estimates for hornblenditic xenoliths suggest equilibration within the lower crust.
\end{abstract}




\section{Introduction}

Alkaline magmas commonly carry mafic and ultramafic xenoliths that constitute a valuable source of information on the nature of the upper mantle and the mantle-lower crust boundary (Nixon, 1987; McDonough, 1990; Downes, 1993; Griffin et al., 1999). The alkaline dyke swarm of the Spanish Central System (SCS) has three main outcrops (Peguerinos, Bernuy Salinero and San Bartolomé de Pinares) (Fig. 1), where scarce pyroxenite and hornblenditic xenoliths are recorded. No unambiguous peridotite xenoliths have been found in any of the SCS lamprophyres.

Although peridotitic xenoliths are usually more common than pyroxenites, both types are commonly associated in alkaline volcanic rocks. Most pyrox- enites are interpreted as fragments of high pressure crystal-segregations from melts flowing through conduits in the mantle or crystallised in magma chambers ( ilshire and Shervais, 1975; Frey, 1980; Irving, 1980; Bødinier et al., 1987a,b; Suen and Frey, 1987; Wilkinson and Stolz, 1997; Ho et al., 2000), providing information about fractionation of basaltic magmas in the mantle. Nonetheless, other origins have been advocated, such as solid-state recycling of subducted lithosphere (Allegre and Turcotte, 1986) and derivation by metasomatic fluids or by melt-rock reactions (Garride and Bodinier, 1999). As the SCS alkaline dykes carry an abundant population of granulitic xenoliths, interpreted as the residual counterpart of the outcropping Hercynian granitic batholith (Villaseca et al., 1999), pyroxenite xenoliths could be also considered part of the

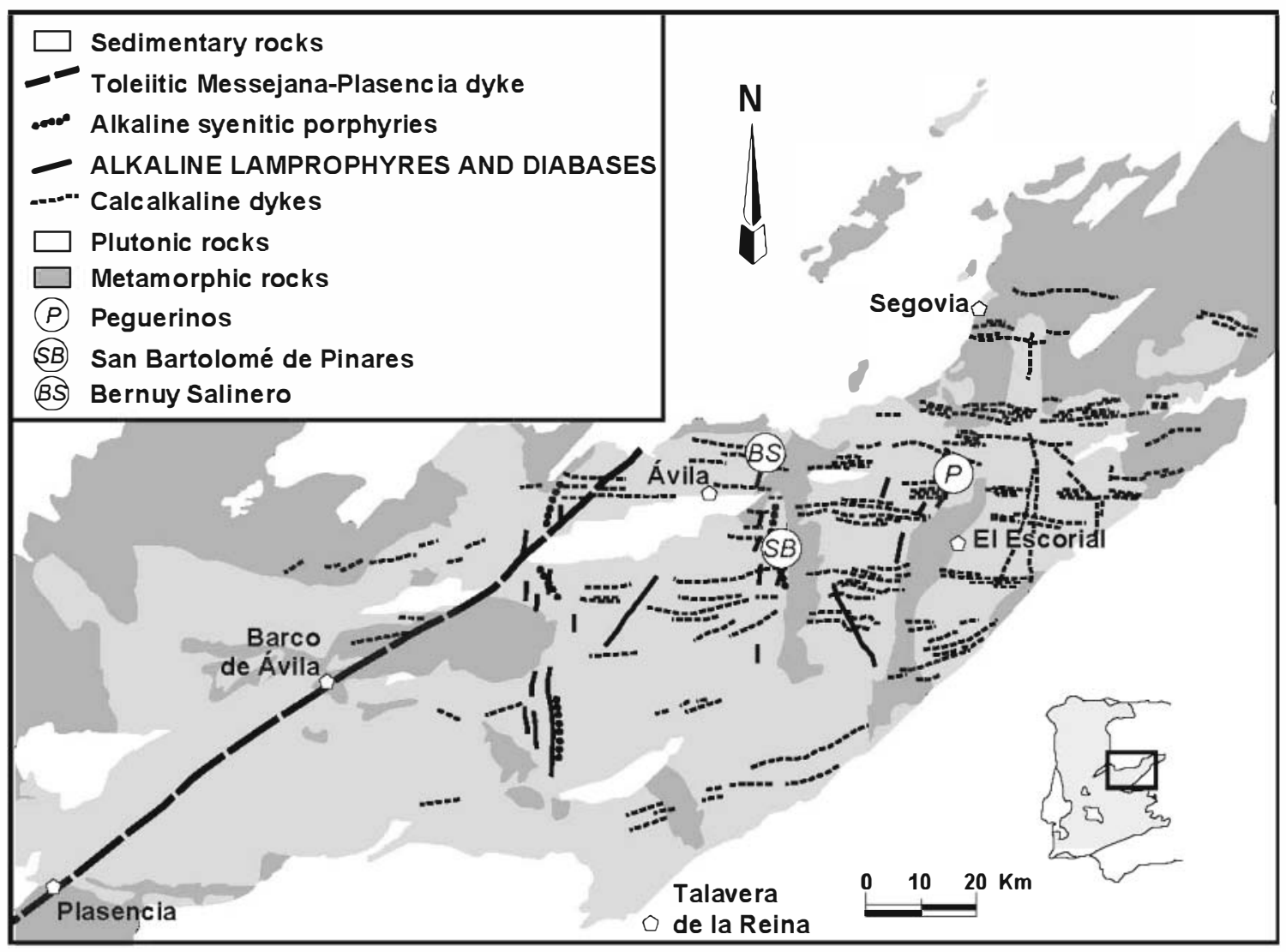

Fig. 1. Sketch map showing location of SCS alkaline lamprophyres and diabases together with other post-Hercynian dyke swarms. Sample localities mentioned in the text are represented as P: Pequerinos, SP: San Bartolomé de Pinares and BS: Bernuy Salinero. 
residual keel of granitoids, as it has been interpreted in the Sierra Nevada batholith (Ducea and Saleeby, 1998; Ducea, 2001, 2002).

Homblende pyroxenite xenoliths within alkaline rocks have been described worldwide (Brooks and Platt, 1975; Wilshire and Shervais, 1975; Vinx and Jung, 1977; Frey and Prinz, 1978; Dautria et al., 1987) and they have often been related to their host (Menzies, 1983; Witt-Eickschen and Kramm, 1998), or considered unrelated, mainly as metasomatized mantle fragments or as cumulates from previous mafic underplating events (Capedri et al., 1989; Frey and Prinz, 1978; Irving, 1980).

Peridotite xenoliths and less frequently pyroxenite and amphibole-rich xenoliths of mantle or lower crustal derivation have been described in different areas of the Iberian Peninsula (Ancochea and Nixon, 1987; Capedri et al., 1989) and from western and central Europe (Becker, 1977; Praegel, 1981; Hunter and Upton, 1987; Downes et al., 2001; Upton et al., 2001; Downes et al., 2002; Carraro and Visonà, 2003; Witt-Eickschen and Kramm, 1998). These xenolith suites are mainly enclosed within host alkaline volcanic rocks with ages ranging from Cenozoic to Quaternary times. Much less frequently ultramafic xenoliths have been described in Palaeozoic igneous rocks, mainly in the British Isles (Praegel, 1981; Hunter and Upton, 1987; Downes et al., 2001; Upton et al., 2001). Recently, some ultramafic xenolith suites from the Cenozoic Puy Beaunit volcano (French Massif Central) have been dated at $257 \pm 6 \mathrm{Ma}$ (U-Pb in zircon, Féménias et al., 2003). The ultramafic xenoliths described in this paper represent the first occurrence of mantle xenoliths belonging to a Palaeozoic subcontinental upper mantle under the Iberian Peninsula.

In this work, we present a geochemical data set for mafic and ultramafic pyroxenitic and related homblenditic xenoliths in the Permian alkaline dykes of the SCS (bulk geochemical and isotopic analyses), together with laser ablation ICP-MS trace element microanalyses of the main mineral components. We discuss the processes involved in their origin and the nature of their sources, by estimating melts in equilibrium with xenolithic clinopyroxene and amphibole, and the possible connection between host dykes and xenoliths.

\section{Geological background}

The Spanish Central System is an orogenic terrane mainly composed of Hercynian granites in its central part. This granitic batholith was later intruded during Permian to Jurassic times by several different dyke suites. These dykes consist of calcalkaline, shoshonitic, alkaline and tholeiitic types (Villa eca et al., 2004) (see map in Fig. 1). The alkaline dyke swarms can be divided into two groups: (i) basic to ultrabasic lamprophyres (mainly camptonites) and closely related diabases, and (ii) red gabbroic to syenitic porphyries. Ultramafic xenoliths have only been found in the ultrabasic members of the alkaline dyke suite.

The age of these lamprophyres and diabases is currently unresolved. They have been dated at $283 \pm 30$ Ma (Rb-Sr isochron; Bea et al., 1999), $277 \pm 5 \mathrm{Ma}(\mathrm{K}-\mathrm{Ar}$ in phlogopite, Villaseca et al., 2004) and $264 \pm 1.3 \mathrm{Ma}$ (Ar-Ar in amphibole, Perini et al., 2004), but the geochronological data are still poorly constrained in such a complex dyke swarm. A Permian age of $270 \mathrm{Ma}$ is used here for isotopic calculations.

SCS alkaline dykes constitute a heterogeneous suite according to their geochemical and petrologic characteristics (Villaseca and de la Nuez, 1986; Bea and Corretge, 1986; Bea et al., 1999; Villaseca et al., 2044). Together with ultramafic xenoliths, they also carry kaersutite, clinopyroxene and plagioclase megacrysts, probably xenocrystic minerals. Lamprophyres show a significant compositional range that is also reflected in their Sr and Nd isotopic ratios. These have depleted to enriched compositions (Villaseca et al., 2004), extending over the whole OIB field. An origin by melting of an enriched subcontinental upper mantle at depths of between 60 and $85 \mathrm{Km}$ is proposed for this magmatism (Bea et al., 1999; Villaseca et al., 2004).

The ultrabasic alkaline dykes carry several types of xenoliths (Villaseca et al., 1983, 1999; Villaseca and de la Nuez, 1986; Orejana and Villaseca, 2003):

1. Granitic and metamorphic xenoliths similar to the wall rocks.

2. Lower-crustal granulitic xenoliths.

3. Mafic and ultramafic xenoliths.

The widespread granulitic xenoliths have been initially classified into three main types (Villaseca et al., 
1999): (i) felsic to intermediate chamockites, (ii) metapelites and (iii) felsic meta-igneous types; the last group represent around $95 \%$ in volume of the total of the granulitic xenolith suite. These xenoliths likely come from different levels of the lower crust and their origin has been explained as granulitic residua after granitic melt extraction.

Ultramafic xenoliths represent much less than $1 \%$ in volume of the total xenolith population carried by the alkaline dykes. These rare mafic and ultramafic xenoliths have been classified into four types according to their petrography and major element mineral chemistry (Orejana and Villaseca, 2003):

1. Highly altered ultramafic xenoliths which preserve $\mathrm{Mg}$ and $\mathrm{Cr}$-rich diopsides, brown spinel and edenitic amphibole. Fresh olivine has never been found in this type of xenoliths.

2. Pyroxenite xenoliths: clinopyroxenites and websterites with Al-rich, Cr-poor augite clinopyroxene and Al-rich orthopyroxene and green pleonaste. They never contain hydrated minerals (homblende, phlogopite).

3. Pyroxenite xenoliths with hydrated minerals: clinopyroxenites with $\mathrm{Cr}$-rich clinopyroxene, pargasitic amphibole and Ti-rich phlogopite. Spinel is always absent.

4. Hornblenditic xenoliths: gabbroic, hornblenditic and homblende clinopyroxenitic xenoliths showing a heterogeneous mineralogical composition (clinopyroxene, kaersutite-pargasite, plagioclase, black spinel, Ti-rich phlogopite, apatite, carbonate, analcite and pseudomorphs of olivine). Clinopyroxene and kaersutite have a wide compositional range characterised by high $\mathrm{Ti}$ and low $\mathrm{Cr}$ contents.

Types 2 and 4 are by far the most abundant ultramafic xenoliths in the SCS lamprophyres. Orejana and Villaseca (2003) relate the highly altered ultramafic xenoliths to the Cr-diopside suite of Wilshire and Shervais (1975), also called group I by Frey and Prinz (1978); types 2 and 4 xenoliths are related to Al-augite enclaves (Wilshire and Shervais, 1975; group II of Frey and Prinz, 1978); whereas type 3 pyroxenites cannot be so easily classified within one of these groups. A cumulate origin from basaltic melts has been proposed for most of the SCS ultramafic xenoliths, and a possible linkage with the lamprophyric or diabasic melts of the host dykes is a question to be discussed (Orejana and Villaseca, 2003). Amphibole megacrysts are also abundant in the outcrops where xenoliths are found.

Two types of ultramafic xenoliths have been studied in this work: (a) pyroxenite xenoliths, which correspond to type 2 pyroxenites of Orejana and Villaseca (2003), and (b) homblenditic xenoliths, which correspond to type 4 xenoliths of Orejana and Villaseca (2003). We do not include xenoliths from types 1 and 3 in this work because they are highly altered (>75 vol.\% of secondary minerals in most cases) and typically very small.

Hornblenditic xenoliths mostly appear in one outcrop (Bernuy Salinero), whereas pyroxenite xenoliths have been found in three different outcrops around Peguerinos and in San Bartolomé de Pinares (Fig. 1). Nevertheless, due to their larger size, homblenditic xenoliths represent more than 50 vol. $\%$ of sampled ultramafic xenoliths.

\section{Analytical techniques}

Major element mineral composition was determined at the Centro de Microscopía Electrónica "Luis Bru" (Complutense University of Madrid) using a Jeol JZA-8900 M electron microprobe with four wavelength dispersive spectrometers. Analyses were performed with an accelerating voltage of 15 $\mathrm{kV}$ and an electron beam current of $20 \mathrm{nA}$, with a beam diameter of $5 \mu \mathrm{m}$. Elements were counted for 10 $\mathrm{s}$ on the peak and $5 \mathrm{~s}$ on each background position. Corrections were made using ZAF method.

Concentrations of 27 trace elements (REE, Ba, Rb, $\mathrm{Th}, \mathrm{U}, \mathrm{Nb}, \mathrm{Ta}, \mathrm{Pb}, \mathrm{Sr}, \mathrm{Zr}, \mathrm{Hf}, \mathrm{Y}, \mathrm{V}, \mathrm{Cr}$ and $\mathrm{Ni}$ ) in silicate minerals (clinopyroxene, amphibole and phlogopite) were determined in situ on $>130 \mu \mathrm{m}$ thick polished sections by laser ablation (LA-ICPMS) at the University of Bristol using a VG Elemental PlasmaQuad 3 ICP-MS coupled to a VG LaserProbe II (266 nm frequency-quadrupled Nd-YAG laser). The counting time for one analysis was typically $100 \mathrm{~s}$ (40 $s$ measuring gas blank to establish the background and 60 for the remainder of the analysis). The diameter of laser beam was around $20 \mu \mathrm{m}$. The NIST 610 and 612 glass standards were used to calibrate relative element 
sensitivities for the analyses of the silicate minerals. Each analysis was normalised to $\mathrm{Ca}$ using concentrations determined by electron microprobe. Values reported in Table 5 correspond to single analyses from the same thin section.

Whole rock major and trace element analyses of 7 xenoliths and the 3 host alkaline dykes were determined at the CNRS-CRPG Nancy. The samples were melted using $\mathrm{LiBO}_{2}$ and dissolved with $\mathrm{HNO}_{3}$. Solutions were analysed by inductively coupled plasma atomic emission spectrometry (ICP-AES) for major elements, whilst trace elements have been determined by ICP mass spectrometry (ICP-MS). Uncertainties in major elements are bracketed between 1 and 3\%, excepting $\mathrm{MnO}(5-10 \%)$ and $\mathrm{P}_{2} \mathrm{O}_{5}(>10 \%)$. Carignan et al. (2001) have evaluated the precision of Nancy ICP-MS analyses at low concentration levels from repeated analyses of the international standards $\mathrm{BR}$, DR-N, UB-N, AN-G and GH. The precision for $\mathrm{Rb}$, $\mathrm{Sr}, \mathrm{Zr}, \mathrm{Y}, \mathrm{V}, \mathrm{Ga}$, Hf and most of the REE is in the range 1 to $5 \%$, whereas they range from 5 to $10 \%$ for the rest of trace elements, including Tm. More information on the procedure, precision and accuracy of Nancy ICP-MS analyses is specified by Carignan et al. (2001).

Three dykes together with one amphibole megacryst and 6 ultramafic xenoliths were selected for Sr$\mathrm{Nd}$ isotopic analysis at the CAI de Geocronología $y$ Geoquímica Isotópica of the Complutense University of Madrid, using an automated VG Sector 54 multicollector thermal ionisation mass spectrometer with data acquired in multidynamic mode. Isotopic ratios of Sr and Nd were measured on a subset of whole rock powder. The analytical procedures used in this laboratory have been described elsewhere (Reyes et al., 1997). Repeated analysis of NBS 987 gave ${ }^{87} \mathrm{Sr} /{ }^{86} \mathrm{Sr}=0.710249 \pm 30(2 \sigma, n=15)$ and for the $\mathrm{JM}$ $\mathrm{Nd}$ standard the ${ }^{143} \mathrm{Nd} /{ }^{144} \mathrm{Nd}=0.511809 \pm 20(2 \sigma$, $n=13)$. The $2 \sigma$ error on $\varepsilon(\mathrm{Nd})$ calculation is \pm 0.4 .

\section{Petrography of xenoliths}

The pyroxenite and homblenditic xenoliths of the SCS show a marked textural contrast. Pyroxenite xenoliths always have a metamorphic (crystalloblastic or porphyroclastic) fabric, whereas homblenditic varieties have an igneous-like texture. Recrystallization and crystalloblastic polygonal textures are the commonest in the pyroxenites. They have minerals with a marked lack of twinning and chemical zoning. Moreover, pyroxene crystals never show lamellar exolution. On the other hand, the presence of chemical zoning in some clinopyroxenes, together with idiomorphic habits and the common poikilitic texture of amphibole, enclosing other phases, suggest a magmatic origin for the homblenditic xenoliths. The modal compositions of the xenoliths are listed in Table 1.

\subsection{Pyroxenites}

This group comprises rounded to planar spinel clinopyroxenites and one spinel websterite xenolith that are variable in size $(0.4-3.5 \mathrm{~cm})$ (Table 1) and with a grainsize that almost never exceeds $3 \mathrm{~mm}$. Commonly, they show equigranular granoblastic textures, with well-developed triple junctions. Orthopyroxene and clinopyroxene are uncoloured; the former is usually altered to $\mathrm{Mg}$-rich chlorite whilst the clinopyroxenes display purple reaction rims against the host lamprophyre. Pyroxenite xenoliths usually have interstitial green spinel of up to $13 \%$ in mode and occasionally accessory calcite. Some accessory sulphides appear near the boundary of the xenoliths and are associated with alteration minerals. Secondary brown to yellow Mg-rich chlorite is present as veins or disseminated crystals. Lamprophyric melt can be seen penetrate the xenoliths along cracks and cause local alteration. Hydrous minerals like amphibole and phlogopite are absent. Also remarkable is the absence of olivine in the studied pyroxenitic xenoliths.

The spinel clinopyroxenite 101892 is petrographically different to the other pyroxenite xenoliths in showing a marked cataclastic structure with large porphyroclastic clinopyroxenes $(>1.5 \mathrm{~cm})$ and black spinel crystals ( $>4 \mathrm{~mm}$ ).

\subsection{Hornblenditic xenoliths}

These xenoliths are almost completely restricted to Bernuy Salinero, but similar varieties are present in the San Bartolomé de Pinares outcrop. They have a variable modal composition that corresponds to gabbroic, pyroxenitic and homblenditic types. The main mineralogy consists of uncoloured to purple clinopyroxene, brown amphibole, plagioclase and black spi- 
Table 1

Modal composition and size of SCS pyroxenitic and hornblenditic xenoliths

\begin{tabular}{|c|c|c|c|c|c|c|c|c|c|c|c|c|c|c|c|c|}
\hline \multirow{2}{*}{$\begin{array}{l}\text { Type } \\
\text { Sample }\end{array}$} & \multicolumn{6}{|l|}{ Pyroxenutes } & \multicolumn{10}{|c|}{ Hornblenditic xenoliths } \\
\hline & 101892 & 102131 & 104395 & $104543 \mathrm{D}$ & $104546 \mathrm{C}$ & $104553 \mathrm{~A}$ & 103471 & 103489 & $103657 \mathrm{~A}$ & 104382 & 104385 & 104389 & 104391 & 104392 & 104529 & $104543 B$ \\
\hline Locality* & $\mathrm{P}$ & $\mathrm{P}$ & $\mathrm{P}$ & $P$ & $\mathrm{P}$ & $\mathrm{P}$ & $\mathrm{BS}$ & $\mathrm{BS}$ & SB & $\mathrm{BS}$ & $\mathrm{BS}$ & $\mathrm{BS}$ & BS & $\mathrm{BS}$ & $\mathrm{BS}$ & $\mathrm{P}$ \\
\hline Clinopyroxene & 94.1 & 56.8 & 76.8 & 69.3 & 38.7 & 64.7 & 61.4 & 39.7 & & 59.1 & 0.5 & 68.5 & 12.7 & 76.1 & 66.5 & 33.1 \\
\hline Orthopyroxene & & 32.6 & & & & & & & & & & & & & & \\
\hline Amphibole & & & & & & & 31.6 & 40.4 & 86.1 & 25.2 & 56.6 & 15.1 & 40.5 & 14.1 & 14.2 & 8.7 \\
\hline Phlogopite & & & & & & & 0.8 & & & & & 3.0 & 1.7 & 0.1 & 0.7 & 0.6 \\
\hline Plagioclase & & & & & & & 1.7 & 12.9 & 12.0 & 6.9 & & 9.8 & & 0.2 & & \\
\hline Apatite & & & & & & & 0.3 & 2.8 & & 0.7 & & 0.6 & & & & \\
\hline Spinel & 5.9 & 0.8 & 2.2 & & & 13.0 & 0.8 & 2.0 & 0.9 & 2.7 & 1.6 & 0.9 & 45.1 & 9.3 & & 35.7 \\
\hline Sulphides & & & 1.1 & & & & & & & & & & & & & \\
\hline Calcite & & & 1.1 & & & & 3.4 & 0.6 & & 0.9 & & 0.3 & & 0.2 & & \\
\hline Analcite & & & & & & & & 1.6 & 0.9 & 4.5 & & 1.2 & & & & \\
\hline Altered & & 9.8 & 18.8 & 30.7 & 61.3 & 22.3 & & & & & 41.3 & 0.6 & & & 18.6 & 21.9 \\
\hline Size $(\mathrm{cm})$ & $0.4 \times 2.2 \times 3$ & $2.7 \times 3.5 \times 1.2$ & $1 \times 1.2$ & $1 \times 0.5$ & $1.5 \times 0.7$ & $1 \times 0.6$ & $3.3 \times 1.2$ & $3.3 \times 1.6$ & $1.1 \times 0.3$ & $3.4 \times 1.7$ & $2 \times 0.6$ & $1.8 \times 0.7$ & $2 \times 1.3$ & $2.2 \times 2.8$ & $1 \times 0.5$ & $0.7 \times 0.8$ \\
\hline
\end{tabular}

* P: Peguernos; BS: Bernuy Salinero; SB: San Bartolomé de Pinares. 
nel. Frequently, they have other minerals in minor proportions such as rounded olivine pseudomorphs, interstitial reddish-brown phlogopite-biotite crystals, globular calcite, interstitial to ocelar analcite and subidiomorphic apatite. Crystals show subidiomorphic habits and are usually unzoned, excepting some clinopyroxenes which show uncoloured cores and pale purple rims. Poikilitic amphibole enclosing clinopyroxene and probably olivine pseudomorphs is common, but amphibole can also be included in clinopyroxene as veins, representing intergrowths, or interstitial, as well as plagioclase and analcite. Plagioclase does not show any textural relationship with spinel, being an original igneous mineral in the more gabbroic sectors of the hornblenditic xenoliths. Thus, a subsolidus transformation of spinel to plagioclase by depressurisation is not likely.

Spinel usually appears associated with amphibole as inclusions. Green clinopyroxene is sometimes present in the margins of some xenoliths. The main minerals (clinopyroxene, amphibole, plagioclase and spinel) have variable grainsizes from a few micrometers to more than $1 \mathrm{~cm}$. The margins of the xenoliths can be zoned or show evidence of corrosion by lamprophyric melt.

Similar xenoliths, also accompanied by kaersutite megacrysts, have been described in Pliocene alkaline basalts from Tallante (South-eastern Spain) (Capedri et al., 1989).

\section{Mineral chemistry}

\subsection{Major elements}

\subsubsection{Pyroxenes}

The clinopyroxenes of both xenolith types (pyroxenites and homblenditic xenoliths) have similar compositions to those of the Al-augite series of Wilshire and Shervais (1975) and the group II xenoliths of Frey and Prinz (1978): they have low $\mathrm{MgO}$ (always $<16$ wt.\%) and low $\mathrm{Cr}_{2} \mathrm{O}_{3}(<0.7$ wt.\%) concentrations (Table 2).

Clinopyroxenes of the pyroxenite xenoliths are Crpoor augites to diopsides with $m g$ numbers ranging from 0.77 to 0.85 (Fig. 2). They have high $\mathrm{Al}_{2} \mathrm{O}_{3}$ (711 wt.\%) and low $\mathrm{Na}_{2} \mathrm{O}(0.5-1$ wt.\%) contents and $\mathrm{Cr}_{2} \mathrm{O}_{3}$ is usually below 0.2 wt.\%, reaching a maxi- mum of 0.6 wt.\% in some high $m g$ number clinopyroxenes. $\mathrm{TiO}_{2}$ concentrations are also quite low, ranging from 0.5 to $1.2 \mathrm{wt} . \%$. There is a slight trend to higher $\mathrm{Na}_{2} \mathrm{O}$ and $\mathrm{Al}_{2} \mathrm{O}_{3}$ values and to lower $\mathrm{SiO}_{2}$ and $\mathrm{CaO}$ contents with decreasing $m g$ number (Fig. 2). Orthopyroxenes of the websterite xenolith have a homogeneous composition around $\mathrm{En}_{78}-\mathrm{En}_{80}$ and can be classified as Al-rich, Cr-poor bronzite $\left(\mathrm{Al}_{2} \mathrm{O}_{3}\right.$ from 7.2 to 7.9 wt. $\%$ and $\mathrm{Cr}_{2} \mathrm{O}_{3}$ from 0.01 to 0.05 wt.\%) (Table 2).

The clinopyroxenes from the homblenditic xenolith suite are $\mathrm{Ti}$ and Al-rich, Cr-poor augites to salites. They have wider compositional ranges than those of the pyroxenites: $\mathrm{TiO}_{2} \quad(0.5-2.75 \mathrm{wt} . \%)$; $\mathrm{Na}_{2} \mathrm{O}$ (0.4-1.4 wt.\%); $\mathrm{CaO}$ (17-24 wt.\%); $\mathrm{Al}_{2} \mathrm{O}_{3}$ (4-10 wt.\%) and $m g$ values from 0.62 to 0.84 (Table 2). The heterogeneity in the clinopyroxene composition between samples is accompanied by a core to rim zoned pattern in some crystals from the same xenolith, characterised by a decrease in $m g$ number, $\mathrm{Cr}_{2} \mathrm{O}_{3}$ and $\mathrm{SiO}_{2}$, and an increase in $\mathrm{Al}_{2} \mathrm{O}_{3}, \mathrm{TiO}_{2}$ and $\mathrm{Na}_{2} \mathrm{O}$ towards the rim, as indicated with an arrow in Fig. 2. The scarce green clinopyroxene is Fe-rich ( $m g$ values around 0.65 ) and Ti-poor (sample 103489-23 in Table 2). Similar compositional trends of $\mathrm{Na}, \mathrm{Si}, \mathrm{Ca}$ and $\mathrm{Al}$ with decreasing $m g$ number to those observed in the pyroxenites are seen in the homblenditic xenoliths.

The major element composition of clinopyroxenes from both SCS pyroxenite xenolith suites is similar to that of some clinopyroxenite and hornblendite xenoliths from Northern Scotland (Hunter and Upton, 1987; Upton et al., 2001). This similarities mainly consist of mid to high $\mathrm{Al}$ and $\mathrm{Ti}$ contents, moderate $m g$ values $(0.66-0.86)$ and low $\mathrm{Cr}$ concentrations, which are regarded as typical of segregates from basic alkaline magmas (Wilshire and Shervais, 1975; Frey and Prinz, 1978).

\subsubsection{Amphiboles}

The amphiboles of the homblenditic xenoliths are kaersutites and pargasites following the classification of Leake et al. (1997). As with the clinopyroxenes of this xenolith type, the amphiboles have wide compositional ranges characterised by high $\mathrm{TiO}_{2}$ (from 2.6 to 6.8 wt.\%) and low $\mathrm{Cr}_{2} \mathrm{O}_{3}$ $(<0.3$ wt. $\%)$ contents and $m g$ numbers ranging from 0.56 to 0.77 (Table 3). Amphiboles show 
Table 2

Major element composition of pyroxenes

\begin{tabular}{|c|c|c|c|c|c|c|c|c|c|c|c|}
\hline \multirow{3}{*}{$\begin{array}{l}\text { Type of xerolith: } \\
\text { Sample }\end{array}$} & \multicolumn{9}{|c|}{ Clinopyroxenes } & \multirow{2}{*}{\multicolumn{2}{|c|}{$\begin{array}{l}\text { Onthopysoxctic } \\
\text { Pymxeniles }\end{array}$}} \\
\hline & \multicolumn{4}{|l|}{ Pỵtnxerites } & \multicolumn{5}{|c|}{ Horthlenéitic xerolitts.s } & & \\
\hline & $101892(11)$ & $1021 \div 1(59)$ & $101395(136)$ & $9(0 \leq 5 / 35)(1 / 3)$ & $163.189(2)$ & $103.189(41)$ & $103: k 9(2)$ & $10 \div 3 \times 2(198)$ & $16(k 529(120)$ & $102131(53)$ & $102131(66)$ \\
\hline $\mathrm{SiO}_{2}$ & 47.68 & 48.18 & 50.08 & 49.02 & 50.13 & 47.37 & 47.03 & 47.35 & 48.31 & 51.12 & 50.95 \\
\hline $\mathrm{TiO}_{2}$ & 0.87 & 0.55 & 0.79 & 0.66 & 0.64 & 1.42 & 2.15 & 1.46 & 1.44 & 0.13 & 0.17 \\
\hline $\mathrm{Al}_{2} \mathrm{O}_{3}$ & 9.00 & 9.34 & 7.78 & 7.50 & 5.00 & 8.24 & 9.14 & 8.73 & 7.79 & 7.75 & 7.43 \\
\hline $\mathrm{FeO}_{t}$ & 6.91 & 5.87 & 5.13 & 5.72 & 10.77 & 6.92 & 7.91 & 7.92 & 5.73 & 11.33 & 11.49 \\
\hline $\mathrm{Cr}_{2} \mathrm{O}_{3}$ & 0.00 & 0.02 & 0.25 & 0.58 & 0.06 & 0.21 & 0.04 & 0.00 & 0.25 & 0.01 & 0.02 \\
\hline $\mathrm{MnO}$ & 0.09 & 0.09 & 0.13 & 0.14 & 0.31 & 0.03 & 0.03 & 0.16 & 0.19 & 0.14 & 0.03 \\
\hline $\mathrm{NiO}$ & 0.01 & 0.04 & 0.00 & 0.00 & 0.07 & 0.00 & 0.02 & 0.00 & 0.00 & 0.00 & 0.03 \\
\hline $\mathrm{MgO}$ & 13.45 & 14.26 & 14.72 & 14.46 & 11.22 & 13.05 & 10.89 & 11.94 & 14.49 & 27.01 & 28.03 \\
\hline $\mathrm{CaO}$ & 20.31 & 20.36 & 21.25 & 21.32 & 19.65 & 20.39 & 20.93 & 21.28 & 20.96 & 1.10 & 0.70 \\
\hline $\mathrm{Na}_{2} \mathrm{O}$ & 0.94 & 0.65 & 0.68 & 0.65 & 1.35 & 0.93 & 1.14 & 1.09 & 0.83 & 0.06 & 0.05 \\
\hline $\mathrm{K}_{2} \mathrm{O}$ & 0.00 & 0.02 & 0.02 & 0.01 & 0.00 & 0.00 & 0.00 & 0.00 & 0.00 & 0.01 & 0.02 \\
\hline Total & 99.26 & 99.38 & 100.83 & 92.56 & 99.20 & 98.56 & 99.28 & 99.93 & 99.99 & 98.66 & 98.93 \\
\hline \multicolumn{12}{|c|}{ Cations calculated on the basis of six oxygens } \\
\hline $\mathrm{Si}$ & 1.759 & 1.768 & 1.813 & 1.793 & 1.887 & 1.767 & 1.759 & 1.750 & 1.767 & 1.834 & 1.817 \\
\hline $\mathrm{Al}_{\mathrm{IV}}$ & 0.241 & 0.232 & 0.187 & 0.207 & 0.113 & 0.233 & 0.241 & 0.250 & 0.233 & 0.166 & 0.183 \\
\hline $\mathrm{Al}_{\mathrm{VI}}$ & 0.150 & 0.172 & 0.145 & 0.116 & 0.109 & 0.129 & 0.161 & 0.131 & 0.102 & 0.161 & 0.129 \\
\hline $\mathrm{Ti}$ & 0.024 & 0.015 & 0.022 & 0.018 & 0.018 & 0.040 & 0.060 & 0.041 & 0.040 & 0.004 & 0.005 \\
\hline $\mathrm{Fe}$ & 0.213 & 0.180 & 0.155 & 0.175 & 0.339 & 0.216 & 0.248 & 0.245 & 0.175 & 0.340 & 0.343 \\
\hline $\mathrm{Cr}$ & 0.000 & 0.001 & 0.007 & 0.017 & 0.002 & 0.006 & 0.001 & 0.000 & 0.007 & 0.000 & 0.001 \\
\hline $\mathrm{Mg}$ & 0.740 & 0.780 & 0.794 & 0.788 & 0.630 & 0.726 & 0.607 & 0.658 & 0.790 & 1.444 & 1.490 \\
\hline $\mathrm{Ni}$ & 0.000 & 0.001 & 0.000 & 0.000 & 0.002 & 0.000 & 0.001 & 0.000 & 0.000 & 0.000 & 0.001 \\
\hline $\mathrm{Mn}$ & 0.003 & 0.003 & 0.004 & 0.004 & 0.010 & 0.001 & 0.001 & 0.005 & 0.006 & 0.004 & 0.001 \\
\hline $\mathrm{Ca}$ & 0.803 & 0.801 & 0.824 & 0.835 & 0.792 & 0.815 & 0.839 & 0.843 & 0.821 & 0.042 & 0.027 \\
\hline $\mathrm{Na}$ & 0.067 & 0.046 & 0.048 & 0.046 & 0.099 & 0.067 & 0.083 & 0.078 & 0.059 & 0.004 & 0.004 \\
\hline $\mathrm{K}$ & 0.000 & 0.001 & 0.001 & 0.000 & 0.000 & 0.000 & 0.000 & 0.000 & 0.000 & 0.001 & 0.001 \\
\hline Cation sum & 4.000 & 3.999 & 3.999 & 4.000 & 4.000 & 4.000 & 4.000 & 4.000 & 4.000 & 3.999 & 3.999 \\
\hline $\mathrm{mg}$ & 0.78 & 0.81 & 0.84 & 0.82 & 0.65 & 0.77 & 0.71 & 0.73 & 0.82 & 0.810 & 0.810 \\
\hline \multicolumn{12}{|l|}{ End-members } \\
\hline Wo & 45.65 & 45.40 & 46.36 & 46.33 & 44.75 & 46.36 & 49.50 & 48.14 & 45.82 & 2.31 & 1.44 \\
\hline En & 42.07 & 44.24 & 44.68 & 43.72 & 35.55 & 41.30 & 35.84 & 37.59 & 44.07 & 78.90 & 80.09 \\
\hline Fs & 12.28 & 10.36 & 8.96 & 9.95 & 19.70 & 12.34 & 14.66 & 14.27 & 10.11 & 18.79 & 18.47 \\
\hline
\end{tabular}



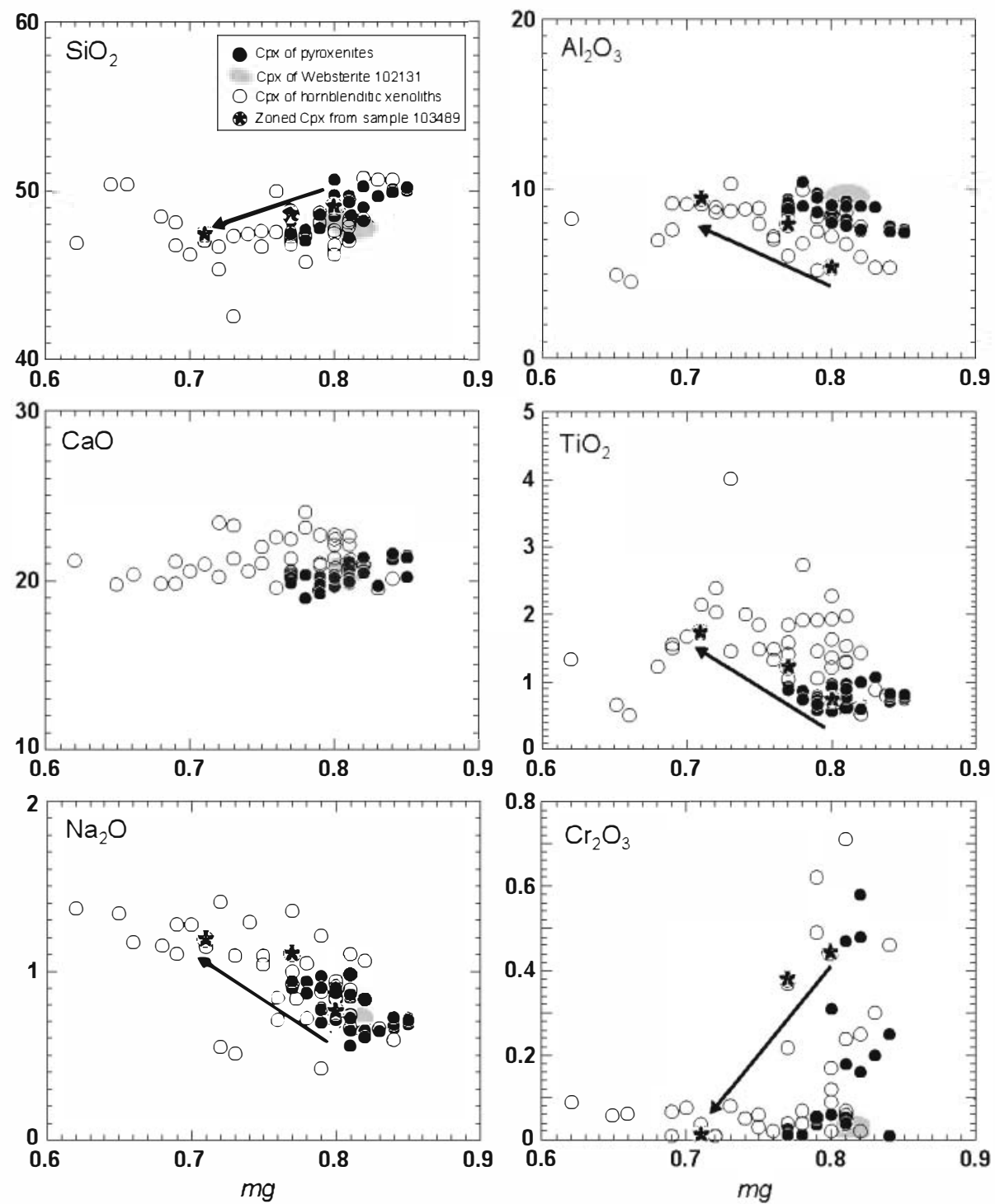

Fig. 2. Variation diagrams for major element compositions of clinopyroxenes from SCS xenoliths. Shaded field corresponds to clinopyroxene composition from websterite xenolith 102131. The arrows display core to rim crystal zoning. Contents of oxides are plotted as wt.\%.

$m g$ numbers close to that of coexisting clinopyroxenes. Considering all the amphibole analyses together, there is a trend towards increasing Ti with decreasing $m g$ values; this trend is also apparent in the $\mathrm{Ca}$ and $\mathrm{K}$ concentrations (both decreasing). Nevertheless, amphibole crystals are not significantly zoned from core to rim. The kaersutite usually has a poikilitic texture, whilst pargasite is interstitial or included within clinopyroxene.

\subsubsection{Other minerals}

The spinels from both types of xenoliths are Al-rich and Cr-poor (Table 4). Nevertheless, there are clear differences between the two types. The pyroxenites have green compositionally more homogeneous pleonaste, with high $\mathrm{Al}_{2} \mathrm{O}_{3}$ ranging from 61 to $66 \mathrm{wt} \%$ and high $m g$ numbers ranging from 0.58 to 0.71 (Fig. 3). The homblenditic xenoliths have Fe-rich black spinel with wider compositional ranges ( $m g$ numbers from 
Table 3

Major element composition of amphiboles

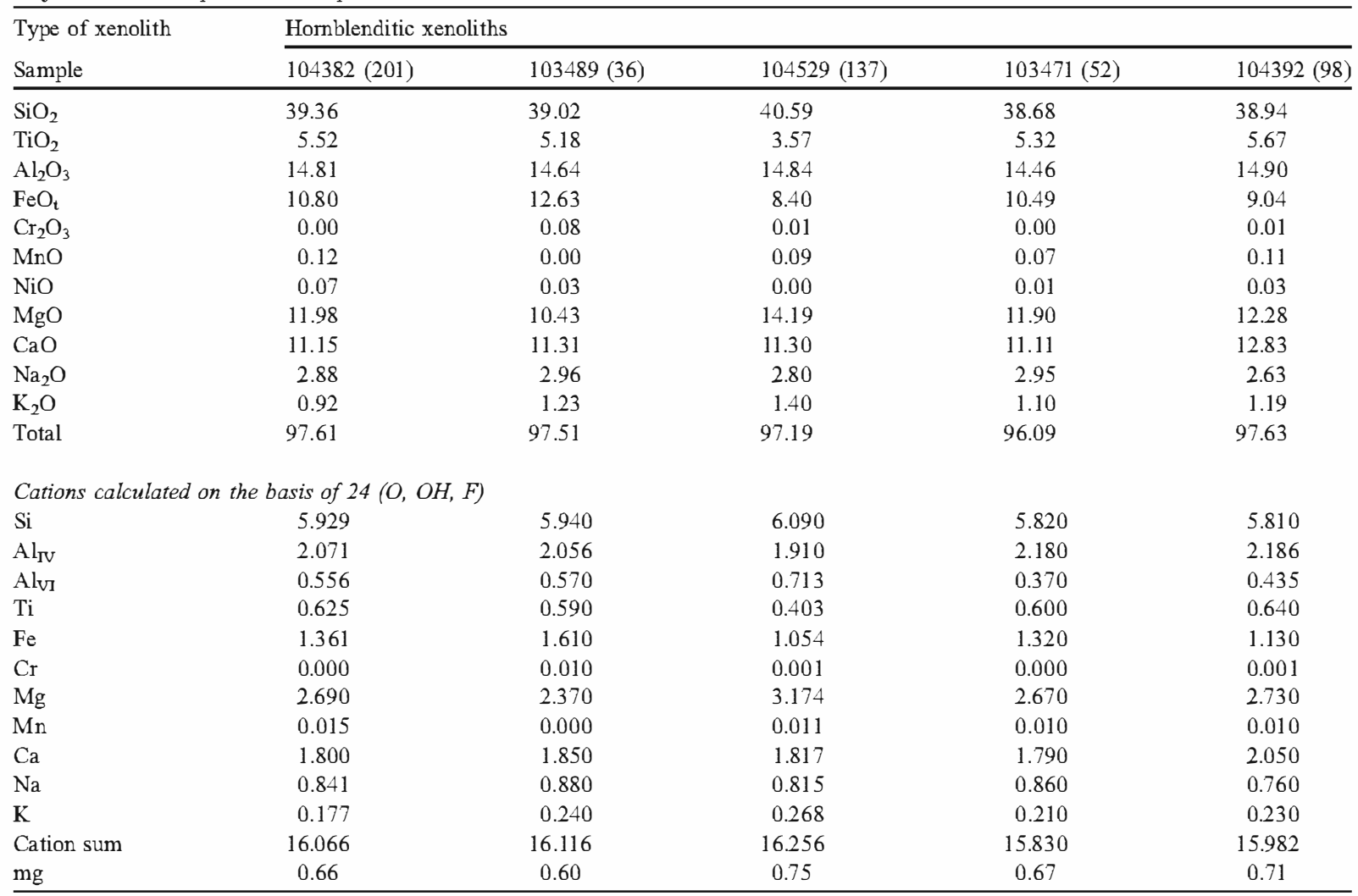

0.36 to $0.56, \mathrm{Al}_{2} \mathrm{O}_{3}$ from 50 to $60 \mathrm{wt} \%$ and slightly higher $\mathrm{TiO}_{2}$ concentrations). The black spinel of sample 101892 (sp-clinopyroxenite xenolith) shows compositional characteristics that connect both groups (Fig. 3 ). Nevertheless, spinels from this cataclastic clinopyroxenite show higher estimated $\mathrm{Fe}_{2} \mathrm{O}_{3}$ concentrations, plotting outside the general trend (Fig. 3).

The hornblenditic xenoliths have Ti-rich, Cr-poor phlogopite-biotite $\left(\mathrm{TiO}_{2}\right.$ ranges from 4.7 to $6.1 \mathrm{wt} . \%$ and $\mathrm{Cr}_{2} \mathrm{O}_{3}<0.2$ wt.\%) (Table 4). These are heterogeneous in composition, reflected in their $m g$ numbers (0.61-0.80) and $\mathrm{SiO}_{2}$ (34-37.5 wt.\%) and $\mathrm{K}_{2} \mathrm{O}$ (7.39.3 wt.\%) concentrations. As with the coexisting clinopyroxene and amphibole, the micas show a slight compositional trend of decreasing $\mathrm{Si}, \mathrm{Ti}, \mathrm{K}$ and $\mathrm{Na}$ with decreasing $m g$ number.

Plagioclase only occurs in hornblenditic xenolithsand has a homogeneous andesine composition $\left(\mathrm{An}_{34}-\mathrm{An}_{48}\right)$.

\subsection{Trace elements}

\subsubsection{Clinopyroxenes}

Clinopyroxenes from both pyroxenite and hornblenditic xenoliths have very similar high REE contents (Table 5), showing convex-upward patterns on chondrite-normalised abundance plots with the peak abundance close to $\mathrm{Sm}$ or Eu. The REE are typically greater than 10 times chondrite concentrations (Fig. 4A).

Multielement primitive mantle-normalised diagrams display similar homogeneous patterns for both types of xenoliths, with $\mathrm{Ba}, \mathrm{Nb}, \mathrm{Sr}, \mathrm{Zr}$ and $\mathrm{Ti}$ showing characteristic troughs. Except for LILE and some other incompatible elements $(\mathrm{Nb}$, $\mathrm{Ta}, \mathrm{Sr}$ and $\mathrm{Zr}$ ), the clinopyroxenes are around 10 times enriched with respect to primitive mantle (Fig. 4B). 


\begin{tabular}{|c|c|c|c|c|c|c|}
\hline \multirow{3}{*}{$\begin{array}{l}\text { Type of xenolith } \\
\text { Sample }\end{array}$} & \multicolumn{4}{|l|}{ Spinel } & \multirow{2}{*}{\multicolumn{2}{|c|}{$\frac{\text { Phlogopite/biotite }}{\text { Hornblenditic xenoliths }}$}} \\
\hline & \multicolumn{2}{|l|}{ Pyroxenites } & \multicolumn{2}{|c|}{ Hornblenditic xenoliths } & & \\
\hline & $101892(8)$ & $104553 \mathrm{~A}(16)$ & $103471(53)$ & 104543B (69) & $103471(103)$ & $104529(135)$ \\
\hline $\mathrm{TiO}_{2}$ & 0.39 & 0.25 & 0.86 & 5.08 & 6.08 & 5.39 \\
\hline $\mathrm{Al}_{2} \mathrm{O}_{3}$ & 60.18 & 63.45 & 57.35 & 31.87 & 16.18 & 16.74 \\
\hline $\mathrm{FeO}^{*}$ & 16.44 & 15.01 & 21.33 & 30.12 & 11.71 & 9.13 \\
\hline $\mathrm{Fe}_{2} \mathrm{O}_{3} * *$ & 6.52 & 2.19 & 5.30 & 12.82 & - & - \\
\hline $\mathrm{MnO}$ & 0.11 & 0.10 & 0.09 & 0.36 & 0.03 & 0.07 \\
\hline $\mathrm{MgO}$ & 17.01 & 17.76 & 13.14 & 7.48 & 14.55 & 17.23 \\
\hline $\mathrm{CaO}$ & 0.00 & 0.00 & 0.00 & 0.00 & 0.02 & 0.06 \\
\hline $\mathrm{Na}_{2} \mathrm{O}$ & 0.00 & 0.01 & 0.00 & 0.00 & 0.58 & 0.75 \\
\hline \multicolumn{7}{|c|}{ Cations calculated on the basis of 32 and 16 oxygens for spinel and mica, respectively } \\
\hline $\mathrm{Si}$ & 0.020 & 0.010 & 0.020 & 0.040 & 5.600 & 5.560 \\
\hline $\mathrm{Ti}$ & 0.060 & 0.040 & 0.140 & 0.970 & 0.710 & 0.620 \\
\hline $\mathrm{Al}$ & 14.990 & 15.510 & 14.940 & 9.530 & 2.961 & 3.011 \\
\hline $\mathrm{Ni}$ & 0.000 & 0.000 & 0.010 & 0.010 & 0.000 & 0.000 \\
\hline $\mathrm{Cr}$ & 0.000 & 0.090 & 0.040 & 2.610 & 0.010 & 0.000 \\
\hline $\mathrm{Mn}$ & 0.020 & 0.020 & 0.020 & 0.080 & 0.000 & 0.010 \\
\hline $\mathrm{Fe}^{2+}$ & 2.860 & 2.590 & 3.890 & 6.160 & 1.520 & 1.170 \\
\hline $\mathrm{Fe}^{3+}$ & 1.020 & 0.340 & 0.870 & 2.360 & - & - \\
\hline $\mathrm{Mg}$ & 5.360 & 5.500 & 4.330 & 2.830 & 3.370 & 3.920 \\
\hline $\mathrm{Ca}$ & 0.000 & 0.000 & 0.000 & 0.000 & 0.000 & 0.010 \\
\hline
\end{tabular}

* Fe content of phlogopite-biotite analyses is expressed as $\mathrm{FeO}_{\text {total }}$.

** $\mathrm{Fe}_{2} \mathrm{O}_{3}$ content in spinel analyses is calculated after Droop (1987).

These data show compositional similarities and display equivalent normalised pattems when compared to pyroxenites and homblendites from several localities in Scotland (Tingwall, Duncansby Ness and Fidra) (Downes et al., 2001; Upton et al., 2001); the French Massif Central (Downes and Dupuy, 1987) and the Eifel (Germany) (Witt-Eickschen and Kramm, 1998). Similar trace element contents, convex-upward REE pattems and negative anomalies in $\mathrm{Ba}, \mathrm{Nb}, \mathrm{Sr}$ and $\mathrm{Zr}$ are common in clinopyroxenes from those European ultramafic xenoliths. Nevertheless, clinopyroxenes from pyroxenites and homblendites from the Eifel (Witt-Eickschen and Kramm, 1998), interpreted as mafic layers or veins within a lherzolitic mantle, show a marked negative anomaly at Th-U, which is absent in the SCS ultramafic xenoliths.

\subsubsection{Amphiboles}

The amphibole trace element compositions from homblenditic xenoliths are shown in Table 5. They show convex-upward REE patterns with a positive $\mathrm{Eu}$ anomaly that closely resemble those of clinopyroxenes, but with higher concentrations (Fig. $5 \mathrm{~A}$ ). This is consistent with cumulate processes as 

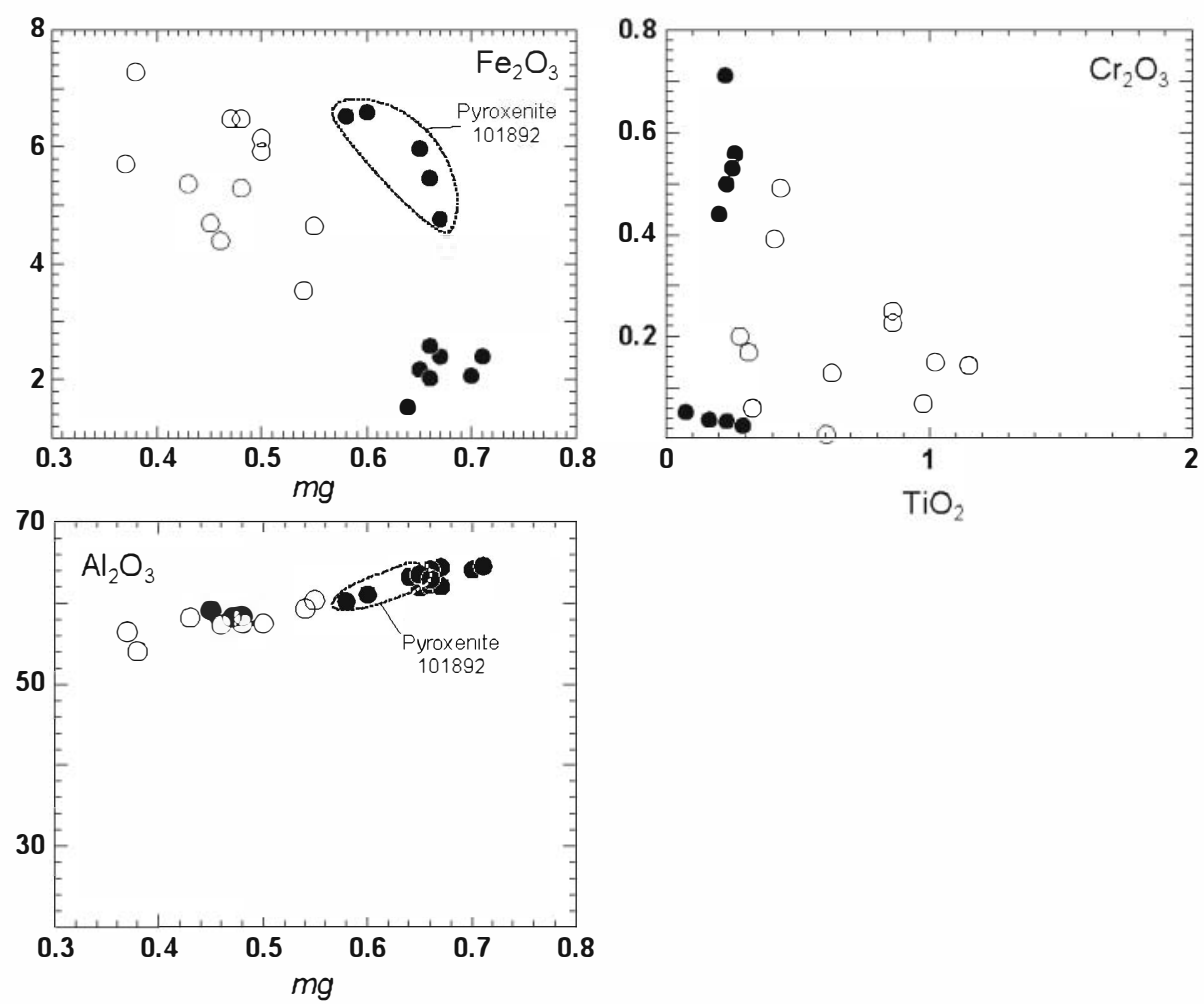

Fig. 3. Variation diagrams for major element compositions of spinels from SCS xenoliths. Contents of oxides are plotted as wt.\%. Spinels from clinopyroxenite xenolith 101892 are marked in some diagrams. $\mathrm{Fe}_{2} \mathrm{O}_{3}$ composition has been estimated following Droop (1987). Symbols as in Fig. 2.

described for Al-augite pyroxenites (Irving and Frey, 1984; Ho et al., 2000). The trace element abundances show characteristic peaks in $\mathrm{Ba}, \mathrm{Nb}$, $\mathrm{Ta}, \mathrm{Sr}, \mathrm{Eu}$ and $\mathrm{Ti}$, and troughs in $\mathrm{Th}$ and $\mathrm{Zr}$ (Fig. 5B). These data are similar to amphiboles from pyroxenitic and homblenditic magmatic segregates (Bodinier et al., 1987a, 1990; Witt-Eickschen and Kramm, 1998; Upton et al., 2001).

\subsubsection{Phlogopites}

Trace element primitive mantle-normalised diagrams of phlogopites from hornblenditic xenoliths are characterised by an irregular pattern with marked troughs at Th and LREE and peaks at $\mathrm{Nb}-\mathrm{Ta}, \mathrm{Sr}$ and $\mathrm{Hf}-\mathrm{Zr}$ (Fig. 6). Nb-Ta contents in phlogopites are comparable with those of the accompanying amphiboles. This feature and the trace element pattems closely resemble those of phlogopites from ultramafic xenoliths that have previously been interpreted as magmatic segregates or the products of crystallization in veins within the mantle (Moine et al., 2000; Ionov et al., 1997).

\section{Bulk chemistry of xenoliths}

\subsection{Major and trace elements}

The major element chemistry of pyroxenites is characterised by phases with higher $m g$ numbers (0.76-0.77) and higher $\mathrm{SiO}_{2}$ and $\mathrm{CaO}$ contents when compared to the homblenditic xenoliths, whilst their $\mathrm{TiO}_{2}, \mathrm{Na}_{2} \mathrm{O}, \mathrm{K}_{2} \mathrm{O}$ and $\mathrm{Fe}_{2} \mathrm{O}_{3}$ concentrations are generally lower (Table 6; Fig. 7). Where heterogeneity exists in the pyroxenites, it is mainly due to presence of orthopyroxene in websterite and Si-poor alteration products in sample 104395, whereas the proportions of clinopyroxene and kaersutite determine the whole-rock composition of the hornblenditic xenoliths. In terms of CIPW normative 

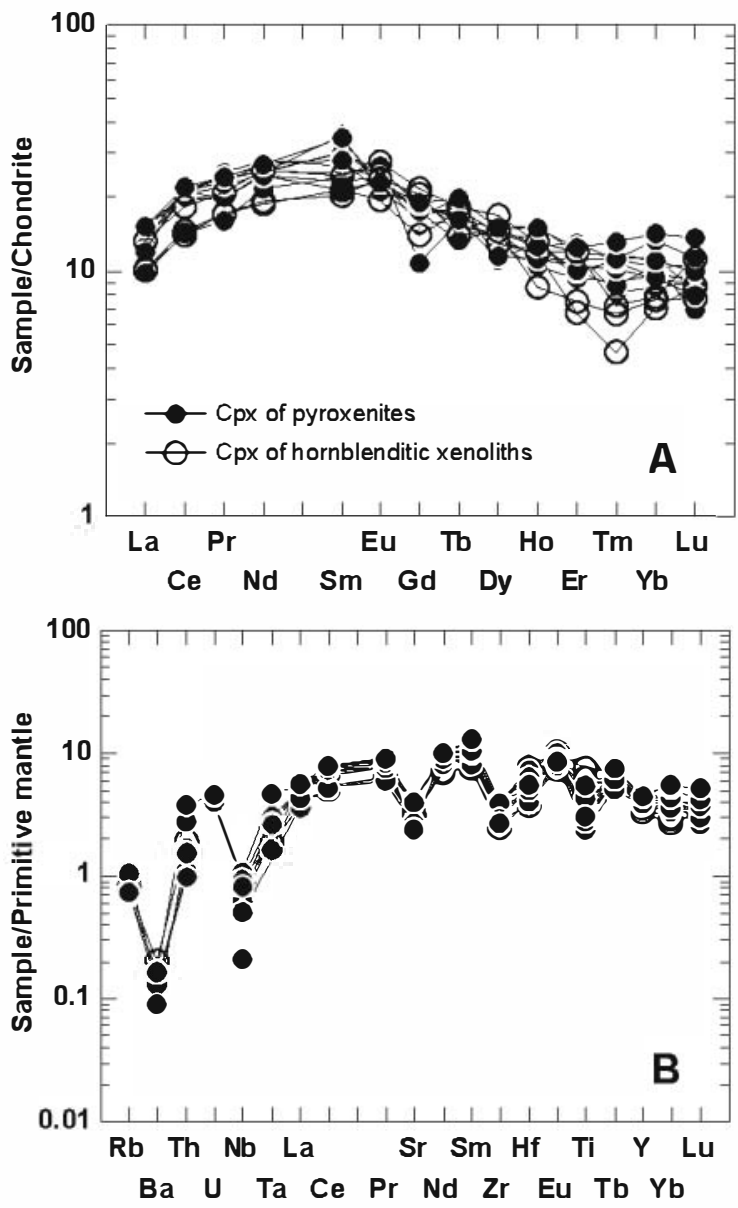

Fig. 4. (A) REE abundances in clinopyroxenes from SCS pyroxenite and hornblenditic xenoliths normalised to chondritic values of Sun and McDonough (1989); (B) trace element abundances in clinopyroxenes normalised to primitive mantle values of $\mathrm{McDonough}$ and Sun (1995). Symbols as in Fig. 2.

compositions, pyroxenite 104395 has 18.7 wt.\% olivine (it would plot as an olivine clinopyroxenite on a Hy-Ol-Di normative diagram) whereas the other pyroxenites have very similar modal and normative proportions.

Within each group, the xenoliths exhibit homogeneous trace element compositions (Table 6). Pyroxenites show convex-upward chondrite-normalised REE pattern (Fig. 8A) which is typical of pyroxene-dominated segregates (McDonough and Frey, 1989). Primitive mantle-normalised trace element abundances show differences in some LILE (Ba, $\mathrm{Rb}$ and $\mathrm{K}$ ) and HFSE ( $\mathrm{Nb}$, Ta and $\mathrm{Ti}$ ), but are similar for other trace elements (Fig. 8B). Xenolith 101892 is poorer in $\mathrm{Rb}, \mathrm{Ba}, \mathrm{Th}, \mathrm{K}$ and $\mathrm{P}$, with respect to the other pyroxenite xenoliths, but has similar MREE and HREE abundance to the hornblenditic suite. Troughs in $\mathrm{Nb}-\mathrm{Ta}, \mathrm{Sr}, \mathrm{P}, \mathrm{Zr}$ and $\mathrm{Ti}$ and a positive peak in $\mathrm{Pb}$ are common in analysed pyroxenite xenoliths, with the exception of clinopyroxenite 101892 which shows low $\mathrm{Pb}$ concentrations ( $<0.9$ ppm) (Fig. 8B).

The hormblenditic xenoliths are generally enriched in REE and other trace elements (specifically LILE and some HFSE: Th, U, Nb, Ta and $\mathrm{Zr}$ ) when compared to the pyroxenites. In addition, they have almost flat LREE patterns from $\mathrm{La}$ to $\mathrm{Nd}$ and steep patterns from $\mathrm{Nd}$ to $\mathrm{Lu}$ (Fig. $8 \mathrm{~A}$ ). Trace element-normalised diagrams show a homogeneous pattern characterised by a positive anomaly at $\mathrm{Nb}-\mathrm{Ta}$ and troughs at $\mathrm{Th}-\mathrm{U}$, $\mathrm{P}$ and $\mathrm{Zr}$ (Fig. 8B). The variable Ti and Sr compositional pattems may be due to differences in rock mode; abundance of kaersutite would control whole rock Ti concentrations and plagioclase would control $\mathrm{Sr}$ concentrations. $\mathrm{Pb}$ concentrations also show marked variability, with some samples displaying positive anomalies, whereas others have negative anomalies (Fig. 8B).

\subsection{Sr-Nd isotopic composition}

The pyroxenites have remarkably heterogeneous initial $\mathrm{Sr}(0.7028-0.7056)$ and $\mathrm{Nd}(0.51211-$ 0.51261 ) isotopic ratios (Table 7) falling at two extremes within the OIB compositional field (Fig. 9). Two of the pyroxenite samples (websterite and altered clinopyroxenite) have more radiogenic compositions, which is characteristic of lithospheric mantle, very common in post-Hercynian basic magmatism (Villaseca et al., 2004), whereas clinopyroxenite 101892 has a very different isotopic signature, similar to the hornblenditic xenolith suite (Fig. 9). This latter group shows a much more homogeneous composition with high $\varepsilon \mathrm{Nd}$ (5.9-6) and low ${ }^{87} \mathrm{Sr} /{ }^{86} \mathrm{Sr}(0.7029-0.7034)$ when compared with the pyroxenites, and they plot near the depleted extreme of the OIB field, close to the MORB compositional field.

The isotopic composition of pyroxenites from different European regions is plotted for comparison in Fig. 10 (isotopic ratios calculated to $270 \mathrm{Ma}$ ). 
Table 5

LA-ICP-MS analyses of mafic minerals from SCS xenoliths

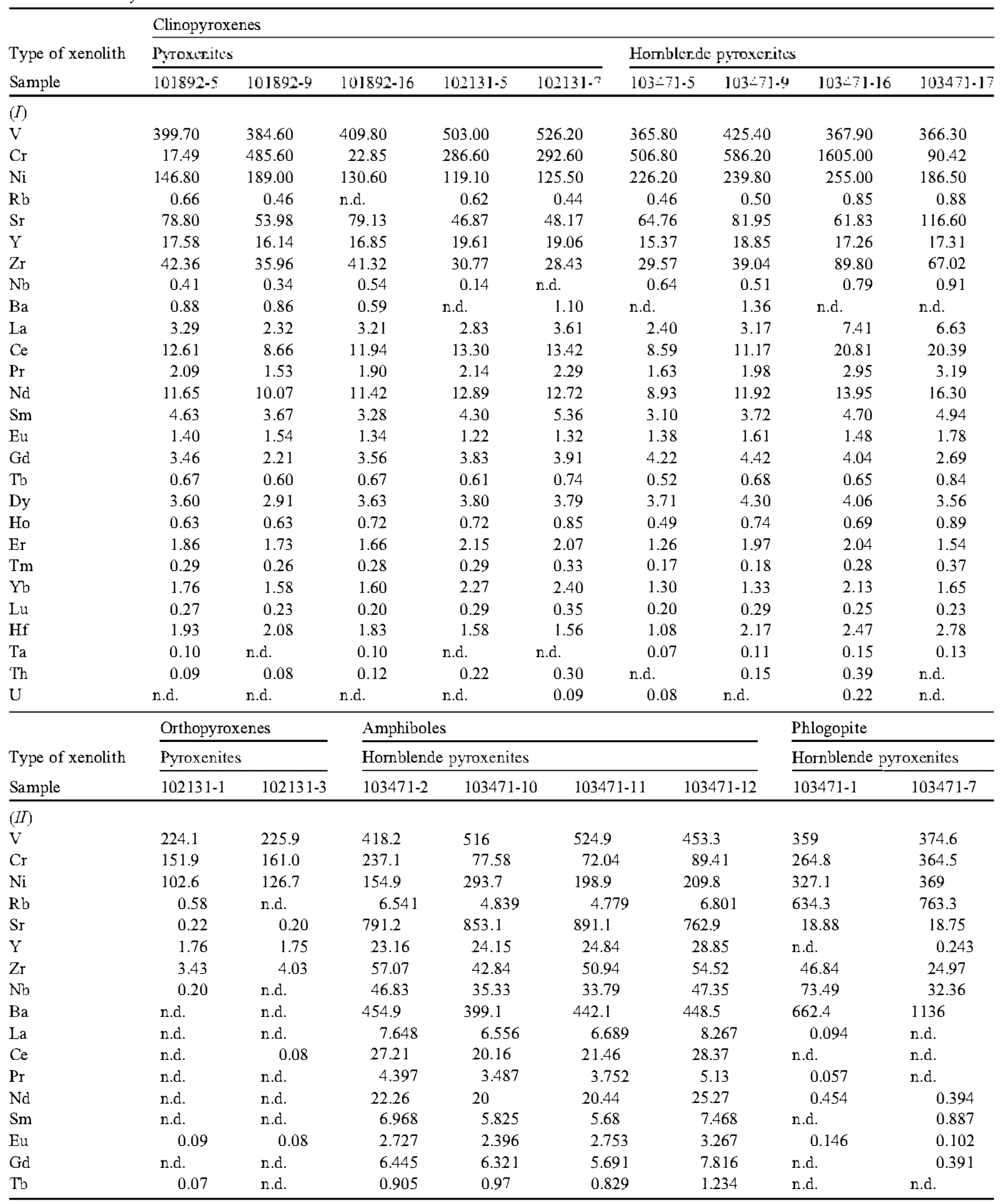




\begin{tabular}{|c|c|c|c|c|c|c|c|c|}
\hline \multirow{2}{*}{$\begin{array}{l}\text { Type of xenolith } \\
\text { Sample }\end{array}$} & \multicolumn{2}{|c|}{ Orthopyroxenes } & \multicolumn{4}{|c|}{ Amphiboles } & \multicolumn{2}{|l|}{ Phlogopite } \\
\hline & 102131-1 & $102131-3$ & $103471-2$ & $103471-10$ & $103471-11$ & $103471-12$ & 103471-1 & $103471-7$ \\
\hline Ho & 0.08 & 0.09 & 0.869 & 0.975 & 0.924 & 1.016 & 0.045 & n.d. \\
\hline Er & 0.23 & 0.38 & 2.1 & 1.884 & 2.243 & 2.569 & n.d. & n.d. \\
\hline $\mathrm{Lu}$ & n.d. & 0.09 & 0.271 & 0.28 & 0.25 & 0.33 & n.d. & n.d. \\
\hline $\mathrm{Hf}$ & 0.17 & 0.25 & 1.897 & 2.1 & 1.821 & 2.059 & 0.977 & 0.582 \\
\hline $\mathrm{Ta}$ & n.d. & n.d. & 2.371 & 1.79 & 1.671 & 2.11 & 4.344 & 2.681 \\
\hline Th & n.d. & n.d. & 0.15 & 0.187 & n.d. & 0.139 & n.d. & 0.08 \\
\hline $\mathrm{U}$ & 0.06 & n.d. & n.d. & 0.049 & n.d. & n.d. & 0.218 & 0.111 \\
\hline
\end{tabular}

n.d.: not detected.

Scottish (Fidra) pyroxenites (Downes et al., 2001) have an isotopic signature very close to that of the homblenditic xenoliths suite, whilst pyroxenitic xenoliths from French Massif Central (FMC), mainly restricted to the Puy Beaunit volcano, plot towards more radiogenic fields (Downes and Dupuy, 1987).

\section{Bulk chemistry of alkaline dykes}

Except in few instances, the SCS alkaline lamprophyres and diabases are ultrabasic in composition and show a predominant potassic character, with $\mathrm{K}_{2} \mathrm{O}$ / $\mathrm{Na}_{2} \mathrm{O}$ ratios ranging from 0.4 to 2.7 . Their $m g$ numbers are variable $(0.42-0.70)$ and have high $\mathrm{TiO}_{2}$ and $\mathrm{P}_{2} \mathrm{O}_{5}$ contents. Based on whole rock geochemistry, they are alkaline lamprophyres (following Reck, 1991), although some would be better classified as diabases due to the presence of plagioclase phenocrysts. They have high LILE contents, around 100 times primitive mantle values (Fig. 8D). Although SCS lamprophyres and diabases show slight differences in trace element composition, their REE chondrite-normalised and trace element primitive mantlenormalised patterns are very similar. The host dykes of Peguerinos, Bernuy Salinero and San Bartolomé de Pinares show similar trace element patterns, with steep REE and characteristic peaks at $\mathrm{Ba}, \mathrm{K}$ and $\mathrm{Ta}$ and troughs at $\mathrm{Pb}, \mathrm{U}$ and $\mathrm{Th}$, falling within the SCS lamprophyre compositional field (Fig. 8C,D). The Peguerinos dyke is slightly depleted in trace elements when compared to the Bernuy Salinero and San Bartolomé de Pinares dykes, and there are some differences in $\mathrm{P}$ and $\mathrm{Zr}$ concentration (Fig. 8D). The high $\mathrm{Ce} / \mathrm{Pb}$ and $\mathrm{Nb} / \mathrm{U}$ ratios of lamprophyres (around 25 and 50, respectively) are in a similar range to OIB values (Wilson, 1989) and they also show a similar trace element pattern, although lamprophyres show higher incompatible trace element contents, mainly in the LILE (Fig. 8D).

The Sr-Nd isotopic ratios of the host lamprophyres are shown in Fig. 9. They plot in two isotopically differentiated fields: one of them falls near the Srdepleted isotopic pole defined mainly by the hornblenditic xenoliths suite, whilst the other field plots close to the enriched extreme corresponding to some pyroxenites. These similarities in their isotopic composition suggest some relationship between the xenoliths and the host alkaline dykes. In both cases, there is a lack of intermediate values between these two compositional poles (Fig. 10).

\section{Discussion}

\section{1. $P-T$ conditions}

Pressure and temperature estimates of the equilibration conditions for the SCS mafic and ultramafic xenoliths have been calculated using geothermobarometers based mainly on clinopyroxene and amphibole compositions. This is due to the absence of unaltered gamet, olivine or orthopyroxene in the ma- 


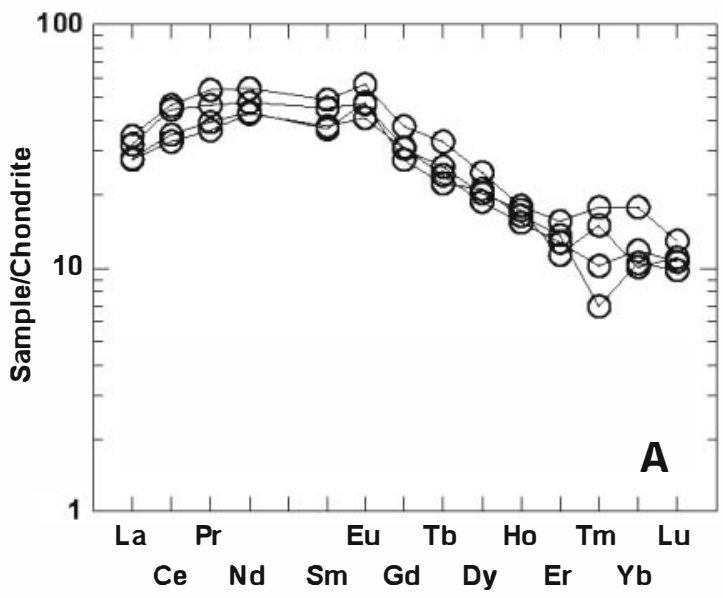

using the Mercier (1980) geothermometer are generally lower than those for the pyroxenites and show a wider range from $848{ }^{\circ} \mathrm{C}$ to $1059^{\circ} \mathrm{C}$, with the exception of sample $104543 \mathrm{~B}\left(1187^{\circ} \mathrm{C}\right)$. These results are clearly controlled by differences in clinopyroxene composition, not only between different xenoliths, but also due to the presence of chemical zoning. The standard deviation $(\sigma)$ for calculated T-values using the Mercier (1980) geothermometer, indicates a narrow variation for pyroxenites (whose clinopyroxenes are homogeneous in composition), with $\sigma$ values from $\pm 6-26^{\circ} \mathrm{C}$, whilst hornblenditic xenoliths have similar $\sigma$-values from \pm 4 to $\pm 27^{\circ} \mathrm{C}$, excluding xenoliths 103471 and 103489, which show higher values $\left( \pm 40\right.$ to $\left.\pm 47{ }^{\circ} \mathrm{C}\right)$. This higher uncertainty is due to wider compositional ranges in clinopyroxenes of these hornblenditic xenoliths. To assess the effect on temperature estimates, we have calculated temperatures for a zoned clinopyroxene crystal from sample 103489 (chemical zoning is shown in Fig. 2). Estimated temperature for the core analysis (which shows the highest $m g$ number) yields $1107^{\circ} \mathrm{C}$, whereas the middle and rim analyses yield 1023 and $834{ }^{\circ} \mathrm{C}$, respectively. The lower T-estimates in other homblenditic xenoliths (in the range $848-927^{\circ} \mathrm{C}$ ) may indicate conditions close to those of clinopyroxene rims, suggesting a relatively lower range of T-estimates for this suite. The geothermometer of Otten (1984), based on the $\mathrm{Ti}$ content in amphibole, has been applied to homblenditic xenoliths, yielding generally higher av-

Fig. 5. (A) REE abundances in amphiboles from SCS hornblenditic xenoliths normalised to chondritic values of Sun and McDonough (1989); (B) trace element abundances in amphiboles, normalised to primitive mantle values of McDonough and Sun (1995).

jority of the xenoliths. Nonetheless, we have applied three thermometers based on two-pyroxene chemistry, to the websterite xenolith (Wood and Banno, 1973; Wells, 1977; Brey and Köhler, 1990). The results are summarised in Table 8.

The average temperatures obtained for single-pyroxene thermometry (Mercier, 1980) in the pyroxenites show a narrow range from $1031{ }^{\circ} \mathrm{C}$ to $1077{ }^{\circ} \mathrm{C}$. Two-pyroxene thermometers yield temperatures in general agreement with those of the Mercier (1980) single-clinopyroxene thermometer, although the latter gives temperatures that are higher by $60-80{ }^{\circ} \mathrm{C}$. The average $\mathrm{T}$-values estimated for homblenditic xenoliths

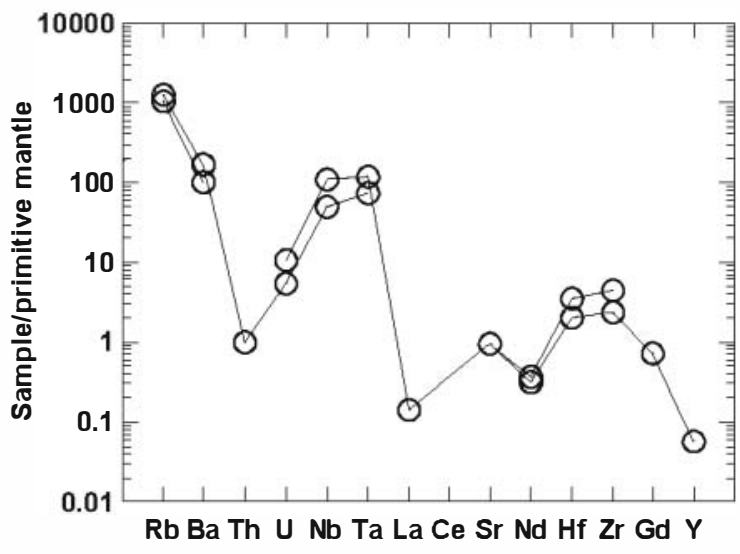

Fig. 6. Trace element abundances in phlogopites from SCS hornblenditic xenoliths normalised to primitive mantle values of McDonough and Sun (1995). 
Table 6

Whole-rock analyses of xenoliths and host rocks

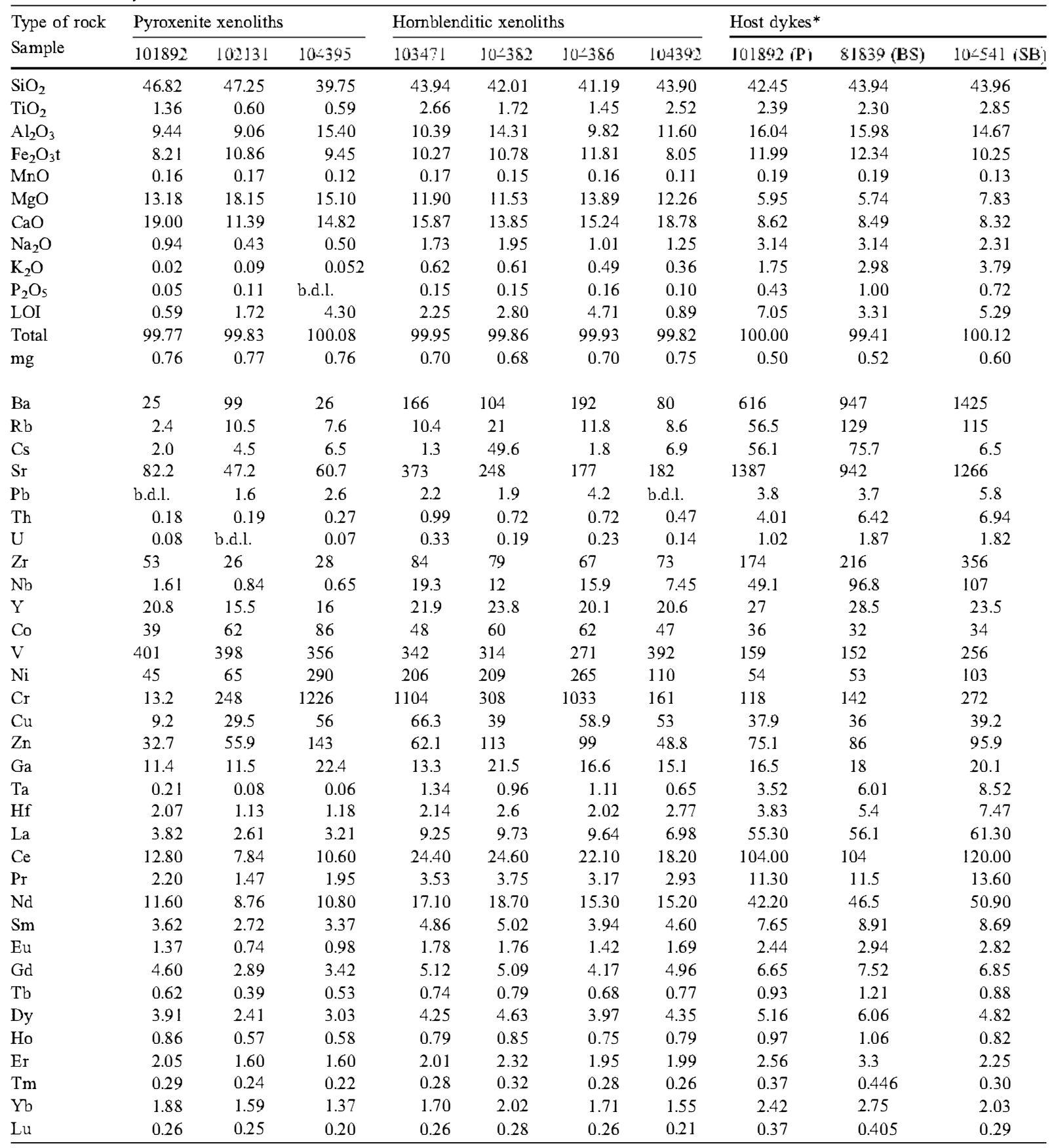

b.d.l.: below detection limit. $\mathrm{P}_{2} \mathrm{O}_{5}<0.05$ wt. $\%, \mathrm{~Pb}<0.9$ ppm and $\mathrm{U}<0.07$ ppm.

* P: Peguerinos; BS: Bernuy Salinero; and SB: San Bartolome de Pinares. 


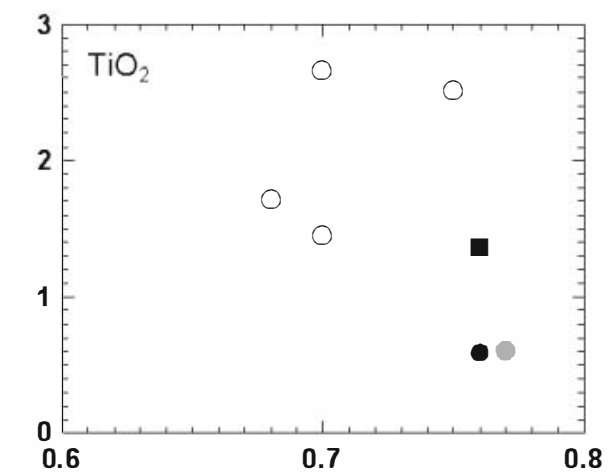

Hornblenditic Xenoliths

- Sp-clinopyroxenite 101892

- Pyroxenite 104395

() Websterite 102131
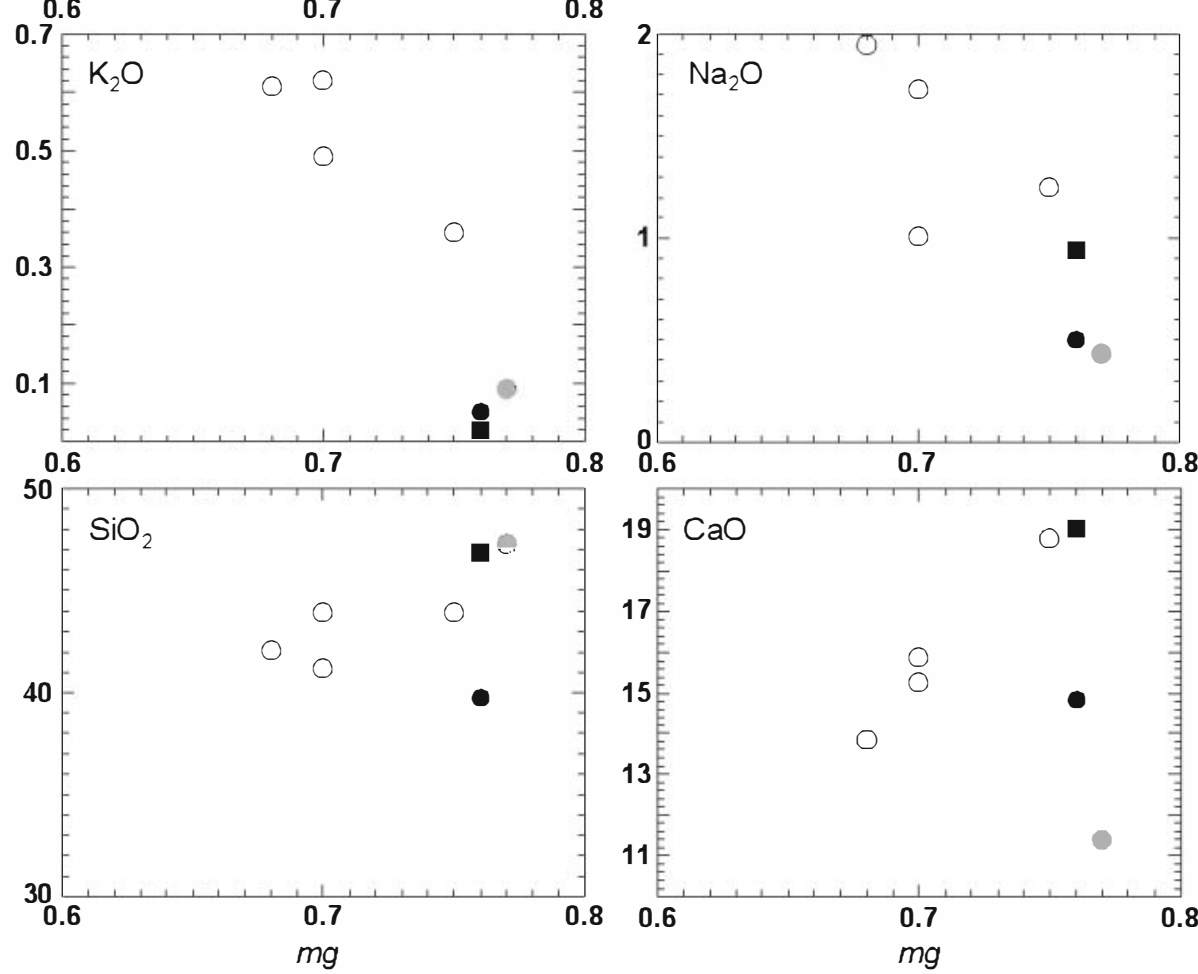

Fig. 7. Diagrams showing major element composition of SCS pyroxenite and hornblenditic xenoliths. Oxide contents are expressed as wt.\%.

$\left.{ }^{\circ} \mathrm{C}\right)$ when compared to those obtained by Mercier (1980) (Table 8).

Pressure estimates are broadly constrained by the absence of gamet from all xenoliths. The experimentally determined low-pressure limit for stability of gamet in pyroxenites is in the narrow range of 1.1 $1.3 \mathrm{GPa}$ (Irving, 1974; Griffin et al., 1984; Hirschmann and Stolper, 1996), that is less than $40 \mathrm{~km}$ in depth. The spinel to plagioclase subsolidus transformation in pyroxenites has a higher uncertainty, but both minerals have been found coexisting at pressures below $0.8 \mathrm{GPa}$ in experiments with a gamet clinopyr oxenite (Irving, 1974), but a more precise lower pressure limit is difficult to establish for the SCS pyroxenitic xenoliths. The presence of plagioclase in homblenditic xenoliths is not related to any recrystallization process after spinel consumption, being an abundant igneous mineral in the more gabbroic sectors of this type of xenolith.

Pressure estimates have been obtained using the barometer of Nimis and Ulmer (1998), which considers only clinopyroxene composition. Pyroxenite xeno- 

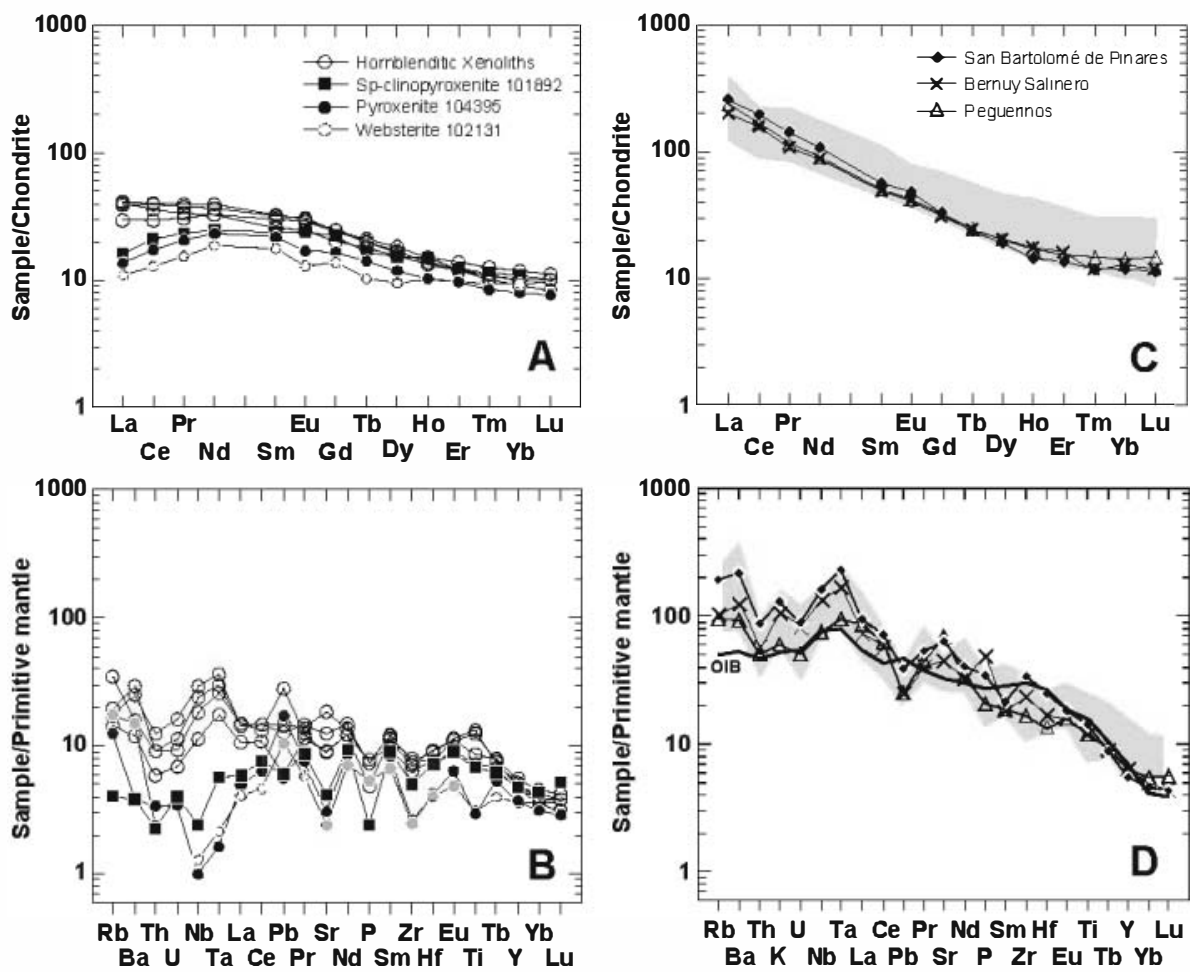

Rb Th U Ta Ce Pr Nd Sm Hf Ti Y Lu $\mathrm{Ba} \mathrm{K} \mathrm{Nb} \mathrm{La} \mathrm{Pb} \mathrm{Sr} \mathrm{P} \mathrm{Zr} \mathrm{Eu} \mathrm{Tb} \mathrm{Yb}$

Fig. 8. (A) Chondrite-normalised REE plots of SCS pyroxenite and hornblenditic xenoliths. (B) Primitive mantle-normalised trace element plots of SCS xenoliths. $\mathrm{Pb}$ negative anomalies in clinopyroxenite 101892 and hornblende clinopyroxenite 104392 are approximated values as in their analyses $\mathrm{Pb}$ content is below detection limit $(0.9 \mathrm{ppm})$. (C) REE chondrite-normalised patterns of SCS alkaline lamprophyres and diabases. (D) Trace elements primitive mantle-normalised patterns of SCS lamprophyres and diabases. The three host dykes are plotted separately and compared with the compositional field (shaded area) of alkaline lamprophyres and an average OIB composition. Chondrite and OIB values after Sun and McDonough (1989) and primitive mantle values after McDonough and Sun (1995). Symbols as in Fig. 7.

liths yield P-estimates ranging from 0.88 to $1.17 \mathrm{GPa}$, except sample 104543D which gives a much lower pressure of $0.77 \mathrm{GPa}$. The hornblenditic xenoliths yield lower pressures from 0.68 to $0.87 \mathrm{GPa}$ (Table 8). Nimis and Ulmer (1998) considered four different compositional pressure calibrations: anhydrous alkaline (BA), hydrous alkaline (BH), tholeiitic (TH) and mildly alkaline (MA). Although the $\mathrm{BH}$ calibration seems to be the best approximation for some of the xenoliths studied here (those with hydrous minerals amphibole and phlogopite), the results obtained, using the Mercier (1980) geothermometer estimated temperatures as a necessary input, are unrealistic. Estimated pressures in hornblenditic xenoliths would range from 1 to $2.4 \mathrm{GPa}$, which should be reflected in the common presence of garnet in most of them, in obvious contradiction with their petrography. On the other hand, Nimis and Ulmer (1998) showed that results obtained using the $\mathrm{BA}$ composition could be underestimated by $0.1 \mathrm{GPa}$ per $1 \mathrm{wt} \%$ of $\mathrm{H}_{2} \mathrm{O}$ in the melt. Thus, the data set presented here is based on the BA calibration, which gives narrower pressure ranges ( $\sigma$-values of $\pm 0.1 \mathrm{GPa})$ in accordance with the mentioned experimental results from pyroxenitic xenoliths (Irving, 1974; Griffin et al., 1984; Hirschmann and Stolper, 1996). The BA pressure calibration of Nimis and Ulmer (1998) is independent of temperature, so the variation in pressure observed in Table 8 is due to the compositional variability of clinopyroxene.

We consider that pressure estimates using the BA calibration are more reliable for the anhydrous paragenesis of pyroxenite xenoliths than for the volatilerich hornblenditic xenoliths. Nevertheless, differences in the range of pressure estimates are small $(0.2-0.3$ $\mathrm{GPa}$ ), and might indicate a deeper lithospheric level of provenance of the pyroxenite xenoliths. 
Table 7

$\mathrm{Sr}$ and Nd concentrations (ppm) and isotope data of SCS xenoliths and host dykes

\begin{tabular}{|c|c|c|c|c|c|c|c|c|c|c|c|}
\hline Sample & Type of rock & $\begin{array}{l}\mathrm{Rb}^{* *} \\
\text { (ppm) }\end{array}$ & $\begin{array}{l}\mathrm{Sr}^{* *} \\
\text { (ppm) }\end{array}$ & ${ }^{87} \mathrm{Rb} /{ }^{86} \mathrm{Sr}$ & ${ }^{87} \mathrm{Sr} /{ }^{86} \mathrm{Sr} \pm(2 \sigma)$ & ${ }^{87} \mathrm{Sr}^{86} \mathrm{Sr}_{270 \mathrm{Ma}}$ & $\begin{array}{l}\mathrm{Sm}^{* *} \\
\text { (ppm) }\end{array}$ & $\begin{array}{l}\mathrm{Nd}^{* *} \\
\text { (ppm) }\end{array}$ & ${ }^{147} \mathrm{Sm}^{1 / 44} \mathrm{Nd}$ & ${ }^{143} \mathrm{Nd} /{ }^{144} \mathrm{Nd} \pm(2 \sigma)$ & $\overline{\varepsilon(\mathrm{Nd})_{270 \mathrm{Ma}}}$ \\
\hline 101892 & Pyroxenite xenolith & 3.4 & 82 & 0.12 & $0.703261 \pm 5$ & 0.70280 & 3.62 & 11.6 & 0.1887 & $0.512943 \pm 4$ & 6.2 \\
\hline 102131 & Pyroxenite xenolith & 10.5 & 47 & 0.64 & $0.707639 \pm 5$ & 0.70517 & 2.72 & 8.8 & 0.1877 & $0.512450 \pm 3$ & -3.4 \\
\hline 104395 & Pyroxenite xenolith & 7.6 & 61 & 0.36 & $0.706989 \pm 6$ & 0.70560 & 3.37 & 10.8 & 0.1886 & $0.512482 \pm 3$ & -2.8 \\
\hline 103471 & Hornblenditic xenolith & 10.4 & 373 & 0.08 & $0.703418 \pm 6$ & 0.70311 & 4.86 & 17.1 & 0.1718 & $0.512901 \pm 3$ & 6.0 \\
\hline 104382 & Hornblenditic xenolith & 21.0 & 248 & 0.25 & $0.704333 \pm 6$ & 0.70339 & 5.02 & 18.7 & 0.1623 & $0.512881 \pm 3$ & 5.9 \\
\hline 104392 & Hornblenditic xenolith & 8.6 & 182 & 0.14 & $0.703419 \pm 6$ & 0.70289 & 4.60 & 15.2 & 0.1830 & $0.512919 \pm 3$ & 6.0 \\
\hline 102135 & Amphibole megacryst & 6.1 & 673 & 0.02 & $0.702670 \pm 5$ & 0.70257 & 5.38 & 18.0 & 0.1807 & $0.512907 \pm 3$ & 5.8 \\
\hline $101892(\mathrm{P})^{*}$ & Alkaline dyke & 56.5 & 1387 & 0.11 & $0.703741 \pm 8$ & 0.70329 & 7.65 & 42.2 & 0.1095 & $0.512832 \pm 5$ & 6.8 \\
\hline 81839 (BS)* & Alkaline dyke & 129 & 942 & 0.39 & $0.705276 \pm 12$ & 0.70375 & 8.91 & 46.5 & 0.1158 & $0.512860 \pm 5$ & 7.1 \\
\hline $104541(\mathrm{SB})^{*}$ & Alkaline dyke & 115 & 1266 & 0.26 & $0.705798 \pm 7$ & 0.70479 & 8.69 & 50.9 & 0.1032 & $0.512500 \pm 6$ & 0.5 \\
\hline
\end{tabular}

* P: Peguerinos; BS: Bernuy Salinero; and SB: San Bartolome de Pinares.

** Elemental abundances of $\mathrm{Rb}, \mathrm{Sr}, \mathrm{Sm}$ and $\mathrm{Nd}$ are taken from ICP-MS analyses. 


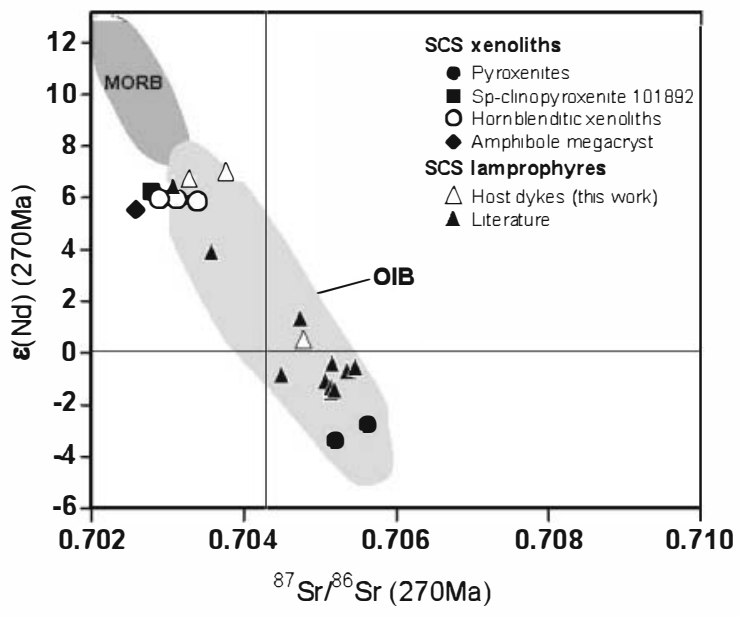

Fig. 9. $\varepsilon(\mathrm{Nd})$ vs. ${ }^{87} \mathrm{Sr} /{ }^{86} \mathrm{Sr}$ at $270 \mathrm{Ma}$ for pyroxenite and hornblenditic xenoliths. Host alkaline dykes are also plotted together with data of SCS alkaline lamprophyres and diabases which are taken from Villaseca et al. (204) and Bea et al. (1999). MORB and OIB fields from Wilson (1989).

We estimate the equilibration depth of the pyroxenite xenoliths, according to the pressure calculations ( $\sim 0.9-1.2 \mathrm{GPa}$ ), to be between 30 and $40 \mathrm{Km}$. Thus, the est mated level is situated close to the lower crustupper mantle boundary, near the Moho. Mohorovicic discont nuity, based on geophysical data, is situated presently between 31 and $34 \mathrm{Km}$ under the SCS region (Sur nach and Vegas, 1988).

$\mathrm{P}-\mathrm{T}$ est mates in the granulitic xenolith suite carried by the lamprophyres, which appears together with the ultramafic xenoliths, yield pressure values ma nly from 0.8 to $1 \mathrm{GPa}$ and temperatures mostly $\mathrm{n}$ the range 850 $950{ }^{\circ} \mathrm{C}$ (Villaseca et al., 1999). These thermodynamic data are very similar to those obta ned $\mathrm{n}$ homblenditic xenoliths (Table 8), suggest ng a lower crustal orig $n$ for these igneous ultramafic mantle derivatives.

$\mathrm{P}-\mathrm{T}$ data calculated for the mafic and ultramafic xenoliths from the SCS suggest a thermal situation under the SCS hotter than expected for a standard Moho level in stable areas. Nevertheless, thermal studies $\mathrm{n}$ this region (Fernández et al., 1998; Tejero and $\mathrm{Ru} z$, 2002) have stated a lithospheric thermal regime which is $\mathrm{n}$ accordance with geotherms reported for ultramafic xenoliths from active tectonic areas (Pearson et al., 2004). Equilibration conditions of the pyroxenitic and hornblenditic xenoliths studied here, at the age of entrapment by the alkal ne Permian dykes, might correspond to hotter geotherms than those from stable or cratonic areas.

\subsection{Origin of pyroxenite xenoliths}

The pyroxenite xenoliths carried by the SCS lamprophyres and diabases can be assigned to the Alaugite series of Wilshire and Shervais (1975) or to group II of Frey and Prinz (1978). The high-Al and low-Cr composition of the orthopyroxene and the presence of green pleonaste sp nel in these xenoliths are also characteristics that allow us to dist nguish these xenoliths from the Cr-diopside series (Wilshire and Shervais, 1975; Frey and Pr nz, 1978).

The absence of olivine and the variable and low concentration of compatible elements such as $\mathrm{Ni}$ (44.9-290 ppm) and Cr (13-1226 ppm) (Table 6) preclude the possibility of the pyroxenites be ng generated as pr mary melts from the partial melting of peridotites.

Cryptic metasomatism of pyroxenites leads to changes $\mathrm{n}$ the chondrite-normalised LREE and MREE patterns and to a selective enrichment of highly incompatible elements over moderately ncompatible elements (Dawson, 1984; Xu, 2002;

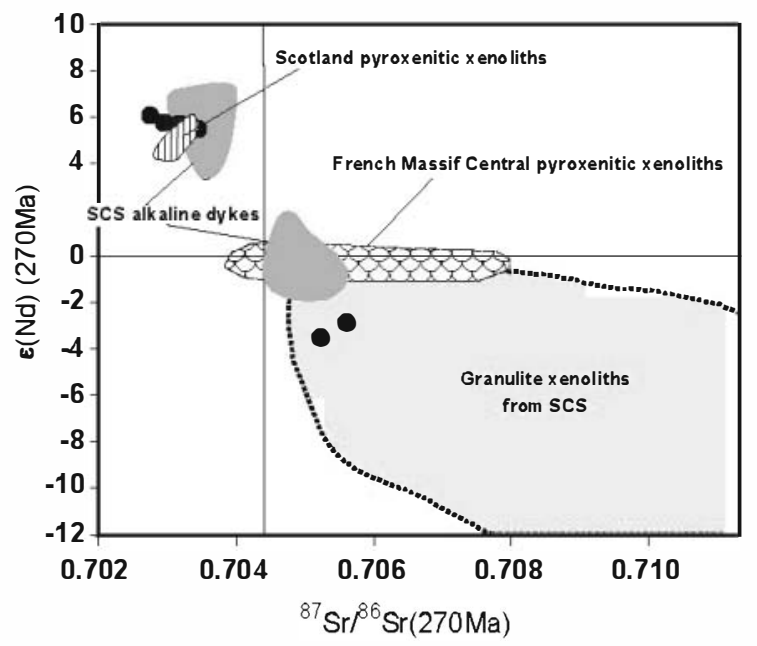

Fig. 10. Sr-Nd compositional fields of different xenolith suites of near Permian age from western and central Europe plotted together with SCS xenolith fields for comparison. Scottish (Fidra) and French Massif Central (FMC) pyroxenitic xenoliths data are taken from Downes et al. (2001), Downes and Dupuy (1987) and Downes et al. (2003). SCS pyroxenite and hormblenditic xenoliths are represented as fiull circles. 
Table 8

$P-T$ estimates for SCS ultramafic xenoliths

\begin{tabular}{|c|c|c|c|c|c|c|c|}
\hline \multirow[b]{3}{*}{ Sample } & \multirow[b]{3}{*}{ Type of xenolith } & \multicolumn{5}{|c|}{ Temperature $\left({ }^{\circ} \mathrm{C}\right)^{*}$} & \multirow{3}{*}{$\frac{\frac{\text { Pressure }(\mathrm{GPa})^{* *}}{\mathrm{cpx}}}{\text { Nimis and Ulmer (1998) }}$} \\
\hline & & \multicolumn{3}{|l|}{ opx-cpx } & \multirow{2}{*}{$\frac{\mathrm{cpx}}{\text { Mercier (1980) }}$} & \multirow{2}{*}{$\frac{\text { Ti in amph }}{\text { Otten (1984) }}$} & \\
\hline & & Wells (1977) & $\begin{array}{l}\text { Wood and Banno } \\
\text { (1973) }\end{array}$ & $\begin{array}{l}\text { Brey and Köhler } \\
\text { (1990) }\end{array}$ & & & \\
\hline 101892 & Pyroxenite & & & & 1051 & & 1.1 \\
\hline 102131 & Pyroxenite & 971 & 1015 & 988 & 1041 & & 1.08 \\
\hline 104395 & Pyroxenite & & & & 1050 & & 0.88 \\
\hline 104543D & Pyroxenite & & & & 1031 & & 0.77 \\
\hline $104546 \mathrm{C}$ & Pyroxenite & & & & 1049 & & 1.17 \\
\hline $104553 \mathrm{~A}$ & Pyroxenite & & & & 1077 & & 1.02 \\
\hline 103471 & Hornblenditic xenolith & & & & 1059 & 1054 & 0.73 \\
\hline 103489 & Hornblenditic xenolith & & & & 1025 & 1022 & 0.68 \\
\hline $103657 \mathrm{~A}$ & Hornblenditic xenolith & & & & & 1031 & \\
\hline 104382 & Hornblenditic xenolith & & & & 918 & 1018 & 0.74 \\
\hline 104385 & Hornblenditic xenolith & & & & 927 & 1018 & 0.87 \\
\hline 104389 & Hornblenditic xenolith & & & & 886 & 988 & 0.68 \\
\hline 104391B & Hornblenditic xenolith & & & & 848 & 1020 & 0.7 \\
\hline 104392 & Hornblenditic xenolith & & & & 850 & 1033 & 0.7 \\
\hline 104529 & Hornblenditic xenolith & & & & 1025 & 977 & 0.77 \\
\hline 104543B & Hornblenditic xenolith & & & & 1187 & 1076 & 0.78 \\
\hline
\end{tabular}

* Temperatures represent the average value for each geothermometer and sample. The standard deviation of the average values for pyroxenites is in the range $6-26^{\circ} \mathrm{C}$, whilst it ranges from $4-27^{\circ} \mathrm{C}$ in hornblenditic xenoliths, except samples 103471 and 103489 with standard deviations of $40-47^{\circ} \mathrm{C}$.

** Pressure represent the average value of each geobarometer and sample. The standard deviation of the average values for hornblenditic xenoliths never exceeds 0.1 GPa. 
Downes et al., 2003). This geochemical fingerprint has been attributed to the chromatographic effect of melt percolation (Navon and Stolper, 1987); however, these features are not apparent in the SCS pyroxenites. Thus, both a metasomatic process and the possible presence of trapped melt in the pyroxenites, are not favoured. Nevertheless, the two lithospheric (isotopically enriched) pyroxenites show a slight LILE ( $\mathrm{Rb}-\mathrm{Ba}$ ) enrichment and a more marked $\mathrm{Nb}$ Ta trough (Fig. 8B).

Pyroxenites may precipitate as veins at different pressures within conduits in the upper mantle (Irving, 1980). However, the absence of composite xenoliths and the scarce presence of peridotitic xenoliths within the SCS xenoliths, together with the moderate pressure estimates (Table 8), favour their formation as intrusive bodies near the mantle-crust boundary or by underplating, as has been suggested for lower crustal xenoliths from other areas (Downes, 1993; Kempton et al., 1995; Litasov et al., 2000). Nonetheless, the presence of highly altered ultramafic xenoliths and lower crustal granulitic xenoliths implies that lamprophyres and diabases sample different lithospheric levels, from the uppermost mantle to the lower crust.

The convex-upwards chondrite-normalised REE patterns are typical of amphibole and clinopyroxene megacrysts precipitated from basic melts at high pressure (Irving and Frey, 1984). This characteristic, together with the low abundance of incompatible elements like $\mathrm{Rb}, \mathrm{Ba}, \mathrm{Th}$ and $\mathrm{Nb}$ in the clinopyroxenes of the xenoliths (Fig. 4), the mineral major element chemistry and their petrography, support a magmatic origin of pyroxenites as cumulates or segregates from basic alkaline melts. The presence of orthopyroxene in some xenoliths also suggests the involvement of more subalkaline silicate melts. Recrystallization textures point to a solid-state residence at depth before being transported by ascending lamprophyric melts. There are some geochemical and petrographic differences between clinopyroxenite 101892 and the other pyroxenites which suggest that their parental melts are not related. This xenolith does not exhibit the negative Eu and $\mathrm{Ti}$ anomalies present in the other pyroxenites, and it shows a less marked $\mathrm{Nb}-\mathrm{Ta}$ trough. It is also depleted in $\mathrm{Pb}$ when compared to the pyroxenites (Fig. 8B).
The trace element composition of parental melts in equilibrium with clinopyroxenes has been calculated using the clinopyroxene/melt partition coefficients of Hart and Dunn (1993), except for Rb from Foley et al. (1996) and Ta from Forsythe et al. (1994). Partitioning is dependent on composition and temperature, so this method can only give a first-order impression of the melt type from which the xenoliths crystallised. Melts based on clinopyroxene composition yield steep chondritic-normalised REE patterns for the pyroxenites that fall within the range of the host lamprophyres and diabases (Fig. 11A). The primitive mantle-normalised diagram for trace elements for the calculated melts falls within the compositional range of that defined by the host dykes, except for Ta that is depleted when compared to the lamprophyres (Fig. $11 \mathrm{~B})$. This suggests that the pyroxenites may have formed from melts similar in composition to the host alkaline dykes.

The isotopic heterogeneity of the pyroxenite xenoliths originating as high-pressure magmatic segregates has three possible interpretations (Wilkinson and Stolz, 1997): (i) crystallization over a large time interval, (ii) crystallization from isotopically variable magmas and (iii) isotopic signatures modified by interaction with wall-rocks or subsequent magmatism. From interpretation (i), only small changes in isotopic composition would be expected, so hypotheses (ii) and (iii) seem more probable. Clinopyroxenite 101892 has clear textural and geochemical differences to the other pyroxenite xenoliths; it has a markedly different isotopic signature that clearly suggests a non-cogenetic origin with regard to other pyroxenites (Fig. 9). Moreover, it has very similar isotopic $(\mathrm{Sr}, \mathrm{Nd})$ ratios to its host alkaline dyke.

The other pyroxenite xenoliths that fall within the OIB field, typically have more enriched lithospheric values and are also near the $\varepsilon(\mathrm{Nd})$-depleted extreme for the range defined by the host lamprophyres and diabases (Fig. 9). It is likely that some of the pyroxenites are not the direct product of host dykes crystallization, due to these isotopic differences, but their geochemical similarities to other lamprophyres and diabases of the same alkaline event suggest that they may have originated from similar sources. 

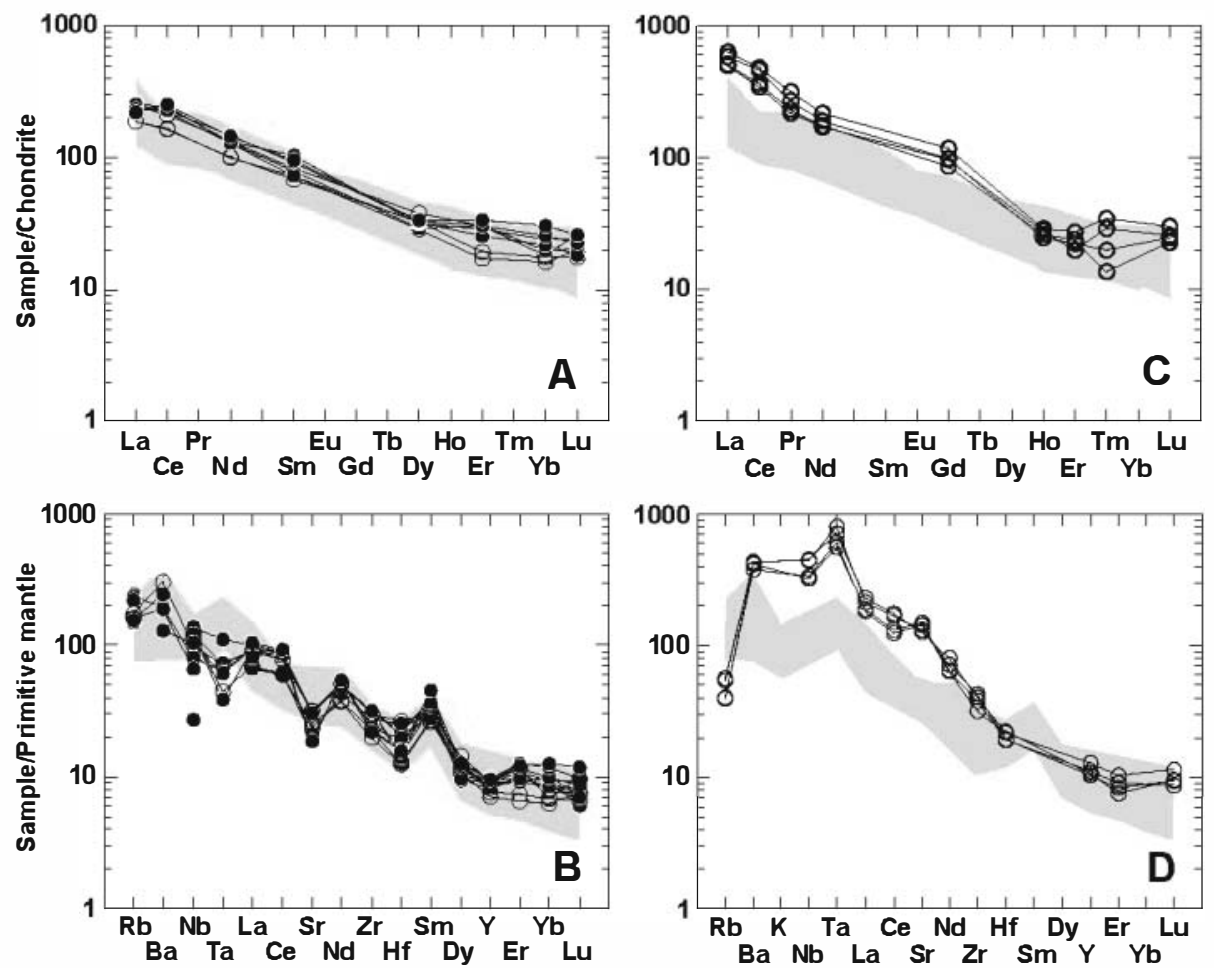

Fig. 11. (A,B) Calculated chondrite normalised (Sun and McDonough, 1989) REE patterns and primitive mantle normalised (McDonough and Sun, 1995) trace element patterns of parent magmas in equilibrium with clinopyroxenes from SCS pyroxenite and hornblenditic xenoliths. Compositional field (shaded area) of SCS alkaline host lamprophyres and diabases is shown for comparison. (C,D) Calculated REE and trace element composition of parent magmas in equilibrium with amphiboles from SCS hornblenditic xenoliths normalised to chondrite and primitive mantle values, respectively. Compositional field (shaded area) of SCS alkaline host lamprophyres and diabases is shown for comparison. Parent magma composition has been calculated using partition coefficients of Hart and Dunn (1993) except for Rb (Foley et al., 1996) and Ta (Forsythe et al., 1994). Lamprophyres and diabases composition are taken from Villaseca and de la Nuez (1986) and Villaseca et al. (2004).

\subsection{Origin of homblenditic xenoliths}

This is the only type of SCS xenoliths that show a clear magmatic cumulate texture. Moreover, they have different, more heterogeneous mineralogical compositions. Nevertheless, although they exhibit differences in major element chemistry with regard to pyroxenite xenoliths, their clinopyroxene trace element geochemistry is very similar, with comparable chondrite and primitive mantle-normalised trace element diagrams (Fig. 4). They can be assigned to the Al-augites series of Wilshire and Shervais (1975) according to their mineral composition and their petrographic characteristics.

Textural observations suggest an olivine-clinopyroxene-amphibole-(plagioclase-phlogopite-spinel) order of crystallization, identical to that experimental- ly determined by Allen et al. (1975) at 1.3 GPa for a water-saturated nephelinite. Absence of fresh olivine may be a consequence of its alteration with increasing melt volatile content (e.g. calcite and analcite ocellum). Clinopyroxene and kaersutite major element chemistry shows wide compositional ranges with linear trends of decreasing $\mathrm{Cr}$ and increasing $\mathrm{Ti}$ with decreasing $m g$ number which is in accordance with a cumulate process.

Orthopyroxene and olivine-poor mafic to ultramafic xenoliths of gabbroic, hornblenditic and pyroxenitic types, carried by basaltic and basanitic melts are also common in other regions and have been described by many authors ( rooks and Platt, 1975; Wilshire and Shervais, 1975; Frey a d Prinz, 1978; Dautria et al., 1987; Reid and Le Roex, 1988; Capedri et al., 1989; Bondi et al., 2002). They have 
been interpreted in most cases as segregates from crystallizing melts.

As was discussed for the pyroxenites, the convex upward REE normalised patterns for the mafic minerals from these xenoliths are consistent with an origin by accumulation processes at high pressures from a basic alkaline magma (Irving and Frey, 1984). Pressures calculated for this group of xenoliths range from approximately 0.7 to $0.9 \mathrm{GPa}$ according to the Nimis and Ulmer (1998) geobarometer (Table 8). This is in agreement with formation at lower crustal levels or in a very shallow upper mantle.

Melts in equilibrium with clinopyroxenes and amphiboles from homblenditic xenoliths have been calculated with the same clinopyroxene/melt partition coefficients used for the pyroxenites (Hart and Dunn, 1993; except Ta following Forsythe et al., 1994) and amphibole/melt partition coefficients of LaTourrette et al. (1995) except for Ta (Dalpé and Baker, 1994). Melts in equilibrium with clinopyroxenes from the homblenditic xenoliths yield steep REE chondriticnormalised pattems that fall within the range of the host lamprophyres and diabases (Fig. 11A). The trace element patterns for the calculated melts are also similar for both types of xenoliths (Fig. 11B). Melts calculated from amphibole compositions also show trace element normalised patterns similar to host dykes compositions (Fig. 11C,D), but with significantly higher values in $\mathrm{Ba}, \mathrm{Nb}, \mathrm{Ta}, \mathrm{LREE}$ and $\mathrm{Sr}$. This suggests that the homblende-bearing xenoliths may also have formed from melts similar in composition to their host alkaline dykes.

Whether these xenoliths are related to their hosts, or represent the crystallization products of different magmas, is more problematic. The trace element composition of melts in equilibrium with clinopyroxene from these hornblenditic xenoliths is very similar to that calculated for the pyroxenites, due to similarities in clinopyroxene geochemistry. Nevertheless, the isotopic signature of these xenoliths is very homogeneous and clearly different from most of the pyroxenites, falling within the field of depleted OIB and near the MORB field (Fig. 9).

There are several major chemical similarities between hornblenditic xenoliths and their host lamprophyres (Table 6). Moreover, their magmatic appearance, without any trace of textural recrystallization, suggests that these volatile-rich xenoliths maintained their original igneous features, and that not much time might has passed between their formation and transport by the alkaline dykes. As for the isotopic composition, the hornblenditic xenoliths coincide with the Nd-enriched field of the lamprophyres, as it occurred with clinopyroxenite 101892, and more specifically with the isotopic composition of the corresponding host lamprophyre (Bernuy Salinero dyke: ${ }^{87} \mathrm{Sr} /{ }^{86} \mathrm{Sr}$ value of 0.70375 and a $\varepsilon \mathrm{Nd}$ value of 7.1) (Fig. 9). All these suggest that the hornblenditic xenoliths were generated by melts geochemically and isotopically similar to the host alkaline lamprophyre. According to the $\mathrm{P}-\mathrm{T}$ estimates discussed above, lamprophyric magmas would have stopped at lower-crustal levels and formed these homblenditic xenoliths by igneous differentiation. A new lamprophyre magmatic pulse would have trapped them before their complete cooling and precluding a recrystallization process. A similar origin for homblendites in Cenozoic alkali basalts from Tallante (Spain) has been proposed by Capedri et al. (1989). These hornblendites and related amphibole megacrysts are interpreted as fractionates from magmas of comparable composition to their host basalts, also formed near the crust-mantle boundary, but small differences in isotope signatures between them point to a non-comagmatic origin.

\subsection{Heterogeneous mantle in central Spain}

The compositional bimodality shown by the ultramafic xenolith suite in the SCS alkaline lamprophyres suggests a heterogeneous mantle beneath central Spain. The presence of granulites and pyroxenites also marks a boundary between these two lithological domains representative of a "petrological Moho", being pyroxenite xenoliths the mantlellic counterpart. In fact, estimated equilibration conditions of the pyroxenite xenoliths give $\mathrm{P}-\mathrm{T}$ estimates that are higher by $\sim 0.2 \mathrm{GPa}$ and $\sim 100{ }^{\circ} \mathrm{C}$ than those of the lower crustal granulitic xenolith suite and that of the homblenditic xenoliths, originated from close-to-Moho magma chambers.

The isotopic composition of pyroxenitic and homblenditic xenoliths and their clear overlap with the lamprophyre compositional fields (Fig. 9) implies that mantle beneath SCS has a "two-pole composition": one a depleted isotopic component with high $\varepsilon \mathrm{Nd}(3.5$ to 7.1$)$ and low ${ }^{87} \mathrm{Sr} /{ }^{86} \mathrm{Sr}$ ratios 
( 0.7029 to 0.7044$)$; the second is an enriched lithospheric mantle with low $\varepsilon \mathrm{Nd}$ values ( -0.9 to 1.5 ) and relatively high ${ }^{87} \mathrm{Sr} /{ }^{86} \mathrm{Sr}$ ratios $(0.7043$ to 0.7051$)$. The lack of any positive correlation of the $\mathrm{Sr}-\mathrm{Nd}$ isotopic composition of the ultramafic xenoliths (Fig. 9) is most likely due to the absence of mixing between the two defined components. This absence of mixing is also shown by the lamprophyre data. The enriched lithospheric signature of mantle derived basic Hercynian and post-Hercynian magmas is common in the SCS (Bea et al., 1999; Villaseca et al., 2004), but OIB mantle values appear exclusively related to post-Hercynian alkaline magmatism. The involvement of a subduction-modified mantle source is not suggested for the genesis of the alkaline suite as all the lamprophyres, irrespectively of their isotopic signature, show high $\mathrm{Ta} / \mathrm{Yb}, \mathrm{Ce} / \mathrm{Pb}$ and $\mathrm{Nb} / \mathrm{U}$ ratios, typical of $\mathrm{OIB}$ values (Villaseca et al., 2004; Perini et al., 2004).

The marked geochemical change in basic magmatism, and the involvement of a new mantle component would require an evolving geodynamic setting, from a post-collisional distensive transtensional setting to a rifting process starting at mid Permian times. This has previously been observed in adjacent areas: the Pyrenees (Debon and Zimmermann, 1993; Innocent et al., 1994; Lago et al, 2004a), the Iberian Range (Lago et al., 2004b) and other places from western Europe (Bonin, 1988; Ziegler, 1993). The involvement of magmas derived from more primitive mantle sources seems to be very limited without the entrainment of a vigorous re-emplacement or convection within the subcontinental lithospheric mantle layers. Later lower Jurassic tholeiitic basic magmatism in the SCS does not show an isotopically depleted OIB mantle component anymore (Cebriá et al., 2003).

Pyroxenite xenoliths of western and central Europe frequently resemble SCS xenoliths in their geochemical and petrological characteristics (Fig. 10). Those of the Eifel (Germany) are considered to have formed from melts genetically related to Quatemary alkaline volcanics (Witt-Eickschen and Kramm, 1998). Scarce pyroxenites from Puy Beaunit (French Massif Central, FMC) have been explained as segregates from melts unrelated to their Tertiary alkaline hosts; a possible linkage with granulites of the lower crust is mentioned (Downes and Dupuy, 1987). They have been recent- ly related to a Permian underplating event in the upper mantle-lower crust boundary (Féménias et al., 2003). The latter suggestion is also invoked for the much more abundant pyroxenites described from Permian alkaline dykes from Northern Scotland (Downes et al., 2001; Upton et al., 2001), where granulites show geochemical similarities to pyroxenites and it has been proposed that these xenoliths formed by underplating as cumulates cogenetic with mafic granulites. Moreover, Permian pyroxenite xenolith suites from FMC and Scotland are similar in isotopic compositions to related mantle xenoliths (e.g. peridotites), but clear peridotitic xenoliths are absent in central Spain. The Scottish ultramafic xenoliths show a more homogeneous isotopic composition towards depleted OIB values close to those of the SCS hornblenditic xenoliths and host alkaline lamprophyres (Fig. 10). The mid Permian alkaline magmatism in Scotland is also related to lithospheric extension (Upton et al., 2001).

French Massif Central pyroxenitic xenoliths also show a restricted range of isotopic values, clearly displaced towards enriched lithospheric fields, similar to those of the SCS websterite and clinopyroxenite 104395 xenoliths. In the FMC, these Permian ultramafic xenoliths are interpreted as cumulates derived from a calcalkaline underplating event, spatially controlled by post-collisional transtensional tectonics in a withinplate continental setting (Féménias et al., 2003).

The wider compositional range and the bimodal distribution of isotopic values in the SCS alkaline lamprophyres and related ultramafic xenoliths, suggest a complex geodynamic environment beneath Central Spain during Permian times. The small outcropping volume of lamprophyres and the limited mafic underplating related to this alkaline magmatism suggest low melt productivity linked to an intracontinental extensional setting.

\section{Conclusions}

The alkaline lamprophyres and diabases of the Spanish Central System carry scarce pyroxenitic and hornblenditic xenoliths which can be divided into two types according to their geochemical and petrological characteristics: (a) pyroxenite xenoliths, consisting of Al-rich, Cr-poor phases and showing recrystallization 
textures, and (b) homblenditic xenoliths with Fe-rich phases and variable compositional ranges showing magmatic textures.

Both types of xenoliths have clinopyroxenes with convex-upwards chondrite normalised REE pattems and low incompatible trace element contents. They are interpreted as segregates formed by the fractional crystallization of alkaline melts. The occurrence of a websterite xenolith implies the presence of a subalkaline component.

$\mathrm{P}-\mathrm{T}$ estimates suggest a deeper lithospheric level of provenance for pyroxenite xenoliths, possibly immediately below the Moho, whereas homblenditic xenoliths could be sampled from stagnant alkaline melts emplaced at lower crustal levels.

The calculated trace element composition of magmas in equilibrium with clinopyroxenes from both types of xenolith closely resembles the range for the host lamprophyres and diabases, implying that these xenoliths formed from melts with a similar composition to the alkaline dykes. Nonetheless, only clinopyroxenite 101892 and the homblenditic xenoliths have isotopic signatures that fall within the isotopic compositional range of their lamprophyre hosts, supporting a possible cogenetic link. The more LILE- and $\mathrm{Pb}$-enriched pyroxenites have enriched lithospheric isotopic compositions that are different to their host alkaline dykes.

Isotopic heterogeneity shown by ultramafic xenoliths and their host lamprophyres suggests two different mantle sources: one which gave rise to the homblenditic xenoliths and some alkaline magmas (depleted OIB pole), whilst the other represents a more radiogenic in $\mathrm{Sr}$ and less radiogenic in $\mathrm{Nd}$ isotopic composition. The isotopically depleted and enriched OIB mantle signatures are exclusively related to the SCS Permian alkaline magmatism, contrasting with the subduction-related signatures shown by the previous basic Hercynian and post-Hercynian magmatic events (Villaseca et al., 2004).

\section{Acknowledgements}

We acknowledge Alfredo Fernández Larios and José González del Tánago for their assistance with the electron microprobe analyses in the CAI of Microscopía Electrónica (UCM) and José Manuel Fuenlab- rada Pérez and José Antonio Hernández Jiménez from the CAI of Geocronología y Geoquímica (UCM) for their help in analysing samples by TIMS. Reviews of the paper by an anonymous reviewer, W.L. Griffin and S.F. Foley greatly enhanced the final version of the manuscript. Laser mineral analyses have been carried out at the Large Scale Geochemical Facility supported by the European Community Access to Research Infrastructure action of the Improving Human Potential Programme, contract number HPRI-CT-1999-00008. This work is included in the objectives of, and supported by, the BTE2000-0575 DGICYT project of the Ministerio de Ciencia y Tecnología of Spain.

\section{References}

Allegre, C.J., Turcotte, D.L., 1986. Implications of a two-component marble-cake mantle. Nature 323, 123-127.

Allen, J.C., Boettcher, A.L., Marland, G., 1975. Amphiboles in andesite and basalt: I. Stability as a function of $\mathrm{P}-\mathrm{T}-\mathrm{f}_{\mathrm{O} 2}$. Am. Mineral. 60, 1069-1085.

Ancochea, E., Nixon, P.H., 1987. Xenoliths in the Iberian Peninsula. In: Nixon, P.H. (Ed.), Mantle Xenoliths. Wiley, Chichester, pp. $119-124$.

Bea, F., Corretge, L.G., 1986. Petrography, geochemistry and differentiation models of lamprophyres from Sierra de Gredos, central Spain. Hercynica 2, 1-15.

Bea, F., Montero, P., Molina, J.F., 1999. Mafic precursors, peraluminous granitoids, and late lamprophyres in the Avila batholith; a model for the generation of Variscan batholiths in Iberia. J. Geol. 107, 399-419.

Becker, H.J., 1977. Pyroxenites and hornblendites from the maartype volcanoes of the Westeifel, Federal Republic of Germany. Contrib. Mineral. Petrol. 65, 45-52.

Bodinier, J.L., Fabries, J., Lorand, J.P., Dostal, J., Dupuy, C., 1987. Geochemistry of amphibole pyroxenite veins from the Lherz and Freychinede ultramafic bodies (Aeriege, French Pyrenees). Bull. Mineral. 110, 345-358.

Bodinier, J.L., Guiraud, M., Fabries, J., Dostal, J., Dupuy, C., 1987. Petrogenesis of layered pyroxenites from the Lherz, Freychinede and Prades ultramafic bodies (Ariege, French Pyrenees). Geochim. Cosmochim. Acta 51, 279-290.

Bodinier, J.L., Vasseur, G., Vernieres, J., Dupuy, C., Fabries, J., 1990. Mechanisms of mantle metasomatism; geochemical evidence form the Lherz orogenic peridotite. J. Petrol. 31, 597-628.

Bondi, M., Morten, L., Nimis, P., Rossi, P.L., Tranne, C.A., 2002. Megacrysts and mafic-ultramafic xenolith-bearing ignimbrites from Sirwa Volcano, Morocco: phase petrology and thermobarometry. Mineral. Petrol. 75, 203-222.

Bonin, B., 1988. From orogenic to anorogenic environments: evidence from associated magmatic episodes. Schweiz. Mineral. Petrogr. Mitt. 68, 301-311. 
Brey, G.P., Köhler, T., 1990. Geothermobarometry in four-phase lherzolites: II. New thermobarometers, and practical assessment of existing thermobarometers. J. Petrol. 31, 1353-1378.

Brooks, C.K., Platt, R.G., 1975. Kaersutite-bearing gabbroic inclusions and the late dike swarm of Kangerdlugssuaq, East Greenland. Mineral. Mag. 40, 259-283.

Capedri, S., Venturelli, G., Salvioli, M.E., Crawford, A.J., Barbieri, M., 1989. Upper-mantle xenoliths and megacrysts in an alkali basalt from Tallante, south-eastern Spain. Eur. J. Mineral. 1, $685-699$

Carignan, J., Hild, P., Mevelle, G., Morel, J., Yeghicheyan, D., 2001. Routine analyses of trace elements in geological samples using flow injection and low pressure on-line liquid chromatography coupled to ICP-MS; a study of geochemical reference materials BR, DR-N, UB-N, AN-G and GH. Geostand. Newsl. $25,187-198$.

Carraro, A., Visonà, D., 2003. Mantle xenoliths in Triassic camptonite dykes of the Predazzo area (Dolomites, northern Italy); petrography, mineral chemistry and geothermobarometry. Eur. J. Mineral. 15, 103-115.

Cebriá, J.M., López-Ruiz, J., Doblas, M., Martins, L.T., Munha, J., 2003. Geochemistry of the Early Jurassic Messejana-Plasencia dyke (Portugal-Spain): implications on the origin of the Central Atlantic Magmatic Province. J. Petrol. 44, 547-568.

Dalpé, C., Baker, D.R., 1994. Partition coefficients for rare-earth elemen between calcic amphibole and Ti-rich basanitic glass at $1.5 \mathrm{Gpa}, 1100^{\circ} \mathrm{C}$. Mineral. Mag. 58, $207-208$.

Dautria, J.M., Liotard, J.M., Cabanes, N., Girod, M., Briqueu, L., 1987. Amphibole-rich xenoliths and host alkali basalts; petrogenetic constraints and implications on the recent evolution of the upper mantle beneath Ahaggar (central Sahara, southern Algeria). Contrib. Mineral. Petrol. 95, 133-144.

Dawson, J.B., 1984. Contrasting types of upper-mantle metasomatism. In: Komprobst, J. (Ed.), Kimberlites: II. The Mantle and Crust-Mantle Relationships. Elsevier, Amsterdam, pp. 289 -294.

Debon, F., Zimmermann, J.L., 1993. Mafic dykes from some plutons of the western Pyrenean Axial Zone (France, Spain): markers of the transition from late-Hercynian to early-Alpine events. Schweiz. Mineral. Petrogr. Mitt. 73, 421-433.

Downes, H., 1993. The nature of the lower continental crust of Europe; petrological and geochemical evidence from xenoliths. Phys. Earth Planet. Inter. 79, 195-218.

Downes, H., Dupuy, C., 1987. Textural, isotopic and REE variations in spinel peridotite xenoliths, Massif Central, France. Earth Planet. Sci. Lett. 82, 121-135.

Downes, H., Upton, B.G.J., Handisyde, E., Thirlwall, M.F., 2001. Geochemistry of mafic and ultramafic xenoliths from Fidra (Southern Uplands, Scotland): implications for lithospheric processes in Permo-Carboniferous times. Lithos 58, $105-124$

Downes, H., Kostoula, T., Jones, P., Beard, D., Thirlwall, F., Bodinier, J.L., 2002. Geochemistry and Sr-Nd isotopic compositions of mantle xenoliths from the Monte Vulture carbonatitemelilitite volcano, central southem I ly. Contrib. Mineral. Petrol. $144,78-93$.

Downes, H., Reichow, M.K., Mason, P.R.D., Beard, A.D., Thirlwall, M.F., 2003. Mantle domains in the lithosphere beneath the
French Massif Central: trace element and isotopic evidence from mantle clinopyroxenes. Chem. Geol. 200, 71-87.

Droop, G.T.R., 1987. A general equation for estimating $\mathrm{Fe}^{3+}$ concentrations in ferromagnesian silicates and oxides from microprobe analyses, using stoichiometric criteria. Mineral. Mag. 51, $431-435$.

Ducea, M., 2001. The California Arc; thick granitic batholiths, eclogitic residues, lithospheric-scale thrusting, and magmatic flare-ups. GSA Today 11, 4-10.

Ducea, M., 2002. Constraints on the bulk composition and root foundering rates of continental arcs: a California arc perspective. J. Geophys. Res. 107 (B11), ECV15.

Ducea, M.N., Saleeby, J.B., 1998. The age and origin of a thick mafic-ultramafic keel from beneath the Sierra Nevada batholith Contrib. Mineral. Petrol. 133, 169-185.

Féménias, O., Coussaert, N., Bingen, B., Whitehouse, M., Mercier, J.C.C., Demaiffe, D., 2003. A Permian underplating event in late- to post-orogenic tectonic setting. Evidence from the maficultramafic layered xenoliths from Beaunit (French Massif Central). Chem. Geol. 199, 293-315.

Fernández, M., Marzán, I., Correia, A., Ramalho, E., 1998. Heat flow, heat production, and lithospheric thermal regimen in the Iberian Peninsula. Tectonophysics 291, 29-53.

Foley, S.F., Jackson, S.E., Fryer, B.J., Greenough, J.D., Jenner, G.A., 1996. Trace element partition coefficients for clinopyroxene and phlogopite in an alkaline lamprophyre from Newfoundland by LAM-ICP-MS. Geochim. Cosmochim. Acta 60, 629-638.

Forsythe, L.M., Nielsen, R.L., Fisk, M.R., 1994. High-field-strength element partitioning between pyroxene and basaltic to dacitic magmas. Chem. Geol. 117, 107-126.

Frey, F.A., 1980. The origin of pyroxenites and garnet pyroxenites from Salt Crater, Oahu, Hawaii; trace element evidence. Am. J. Sci. 280A, 427-449.

Frey, F.A., Prinz, M., 1978. Ultramafic inclusions from San Carlos, Arizona; petrologic and geochemical data bearing on their petrogenesis. Earth Planet. Sci. Lett. 38, 129-176.

Garrido, C.J., Bodinier, J.L., 1999. Diversity of mafic rocks in the Ronda Peridotite; evidence for pervasive melt-rock reaction during heating subcontinental lithosphere by upwelling asthenosphere. J. Petrol. 40, $729-754$.

Griffin, W.L., Wass, S.Y., Hollis, J.D., 1984. Ultramafic xenoliths from Bullenmerri and Gnotuk maars, Victoria, Australia; petrology of a sub-continental crust-mantle transition. J. Petrol. 25, $53-87$.

Griffin, W.L., O'Reilly, S.Y., Ryan, C.G., 1999. The composition and origin of sub-continental lithospheric mantle. In: Fei, Y., Bertka, C.M., Mysen, B.O. (Eds.), Mantle Petrology: Field Observations and High-Pressure Experimentation; A Tribute to Francis R. (Joe) Boyd. Special publication. Penn, Lancaster, pp. $13-45$.

Hart, S.R., Dunn, T., 1993. Experimental cpx/melt partitioning of 24 trace elements. Contrib. Mineral. Petrol. 113, 1-8.

Hirschmann, M.M., Stolper, E.M., 1996. A possible role for garnet pyroxenite in the origin of the "garnet signature" in MORB. Contrib. Mineral. Petrol. 124, 185-208.

Ho, K.S., Chen, J.C., Smith, A.D., Juang, W.S., 2000. Petrogenesis of two groups of pyroxenite from Tungchihsu, Penghu Islands, 
Taiwan Strait; implications for mantle metasomatism beneath SE China. Chem. Geol. 167, 355-372.

Hunter, R.H., Upton, B.J.G., 1987. The British Isles; a Palaeozoic mantle sample. In: Nixon, P.H. (Ed.), Mantle Xenoliths. Wiley, Chichester, pp. 107-118.

Innocent, C., Briqueu, L., Cabanis, B., 1994. Sr-Nd isotope and trace-element geochemistry of late Variscan volcanism in the Pyrenees: magmatism in post-orogenic extension? Tectonophysics $238,161-181$.

Ionov, D.A., Griffin, W.L., O'Reilly, S.Y., 1997. Volatile-bearing minerals and lithophile trace elements in the upper mantle. Chem. Geol. 141, 153-184.

Irving, A.J., 1974. Geochemical and high pressure experimental studies of garnet pyroxenite and pyroxene granulite xenoliths from the delegate basaltic pipes, Australia. J. Petrol. 15, 1-40.

Irving, A.J., 1980. Petrology and geochemistry of composite ultramafic xenoliths in alkalic basalts and implications for magmatic processes within the mantle. Am. J. Sci. 280A, $389-426$.

Irving, A.J., Frey, F.A., 1984. Trace element abundances in megacrysts and their host basalts; constraints on partition coefficients and megacryst genesis. Geochim. Cosmochim. Acta 48, 1201-1221.

Kempton, P.D., Downes, H., Sharkov, E.V., Vetrin, V.R., Ionov, D.A., Carswell, D.A., Beard, A., 1995. Petrology and geochemistry of xenoliths from the northern Baltic Shield: evidence for partial melting and metasomatism in the lower crust beneath an Archaean terrane. Lithos 36, 157-184.

Lago, M., Arranz, E., Pocoví, A., Galé, C., Gil-Imaz, A., 2004. Permian magmatism and basin dynamics in the southern Pyrenees: a record of the transition from late Variscan transtension to early Alpine extension. In: Wilson, M., Neumann, E.R., Davies, G.R., Timmerman, M.J., Heeremans, M., Larsen, B.T. (Eds.), Permo-Carboniferous Magmatism and Rifting in Europe, Spec. Publ. Geol. Soc. London, vol. 223, pp. 439-464.

Lago, M., Arranz, E., Pocoví, A., Galé, C., Gil-Imaz, A., 2004. Lower Permian magmatism of the Iberian Chain, Central Spain, and its relationships to extensional tectonics. In: Wilson, M., Neumann, E.R., Davies, G.R., Timmerman, M.J., Heeremans, M., Larsen, B.T. (Eds.), Permo-Carboniferous Magmatism and Rifting in Europe, Spec. Publ. Geol. Soc. London, vol. 223, pp. 465-490.

LaTourrette, T., Hervig, R.L., Holloway, J.R., 1995. Trace element partitioning between amphibole, phlogopite, and basanite melt. Earth Planet. Sci. Lett. 135, $13-30$.

Leake, B.E., Woolley, A.R., Arps, C.E.S., Birch, W.D., Gilbert, M.C., Grice, J.D., Hawthorne, F.C., Kato, A., Kisch, H.J., Krivovichev, V.G., Linthout, K., Laird, J., Mandarino, J.A., Maresch, W.V., Nickel, E.H., Rock, N.M.S., Schumacher, J.C., Smith, D.C., Stephenson, N.C.N., Ungaretti, L., Whittaker, E.J.W., Youzhi, G., 1997. Nomenclature of amphiboles; report of the subcommittee on amphiboles of the International Mineralogical Association, Commission on New Minerals and Mineral Names. Can. Mineral. 35, 219-246.

Litasov, K.D., Foley, S.F., Litasov, Y.D., 2000. Magmatic modification and metasomatism of the subcontinental mantle beneath the Vitim volcanic field (East Siberia): evidence from trace element data on pyroxenite and peridotite xenoliths from Miocene picrobasalt. Lithos 54, 83-114.

McDonough, W.F., 1990. Constraints on the composition of the continental lithospheric mantle. Earth Planet. Sci. Lett. 101, $1-18$.

McDonough, W.F., Frey, F.A., 1989. Rare earth elements in upper mantle rocks. In: Lipin, B.R., Mckay, G.A. (Eds.), Geochemistry and Mineralogy of Rare Earth Elements, Rev. Mineral., vol. 21 , pp. $99-145$.

McDonough, W.F., Sun, S.S., 1995. The composition of the earth. Chem. Geol. 120, 223-253.

Menzies, M., 1983. Mantle ultramafic xenoliths in alkaline magmas; evidence for mantle heterogeneity modified by magmatic activity. In: Hawkesworth, C.J., Norry, M.J. (Eds.), Continental Basalts and Mantle Xenoliths. Shiva, Nantwich, pp. 92-110.

Mercier, J.C.C., 1980. Single-pyroxene thermobarometry. Tectonophysics 70, 1-37.

Moine, B.N., Cottin, J.Y., Sheppard, S.M.F., Gregoire, M., O'Reilly, S.Y., Giret, A., 2000. Incompatible trace element and isotopic (D/H) characteristics of amphibole- and phlogopite-bearing ultramafic to mafic xenoliths from Kerguelen Islands (TAAF, South Indian Ocean). Eur. J. Mineral. 12, 761-777.

Navon, O., Stolper, E., 1987. Geochemical consequences of melt percolation; the upper mantle as a chromatographic column. J. Geol. 95, 285-307.

Nimis, P., Ulmer, P., 1998. Clinopyroxene geobarometry of magmatic rocks: Part 1. An expanded structural geobarometer for anhydrous and hydrous, basic and ultrabasic systems. Contrib. Mineral. Petrol. 133, $122-135$.

Nixon, P.H., 1987. Mantle Xenoliths. Wiley, Chichester, pp. 844.

Orejana, D., Villaseca, C., 2003. Caracterización mineral de los enclaves máficos y ultramáficos en los lamprófidos alcalinos del Sistema Central Español. Bol. Soc. Esp. Mineral. 26A, $151-152$.

Otten, M.T., 1984. The origin of brown hornblende in the Artfjaellet gabbro and dolerites. Contrib. Mineral. Petrol. 86, 189-199.

Pearson, D.G., Canil, D., Shirey, S.B., 2004. Mantle samples included in volcanic rocks: xenoliths and diamonds. In: Holland, H.D., Turekian, K.K. (Eds.), Treatise on Geochemistry, vol. 2. Elsevier-Pergamon, Oxford, pp. 171-275.

Perini, G., Cebriá, J.M., López-Ruiz, J.M., Doblas, M., 2004. Permo-Carboniferous magmatism in the Variscan belt of Spain and France: implications on mantle sources. In: Wilson, M., Neumann, E.R., Davies, G.R., Timmerman, M.J., Heeremans, M., Larsen, B. (Eds.), Permo-Carboniferous Magmatism and Rifting in Europe, Spec. Publ. Geol. Soc. London, vol. 223, pp. $415-438$.

Praegel, N.O., 1981. Origin of ultramafic inclusions and megacrysts in a monchiquite dyke at Streap, Inverness-shire, Scotland. Lithos 14, 305-322.

Reid, A.M., Le Roex, A.P., 1988. Kaersutite-bearing xenoliths and megacrysts in volcanic rocks from the Funk Seamount in the Southwest Indian Ocean. Mineral. Mag. 52, 359-370.

Reyes, J., Villaseca, C., Barbero, L., Quejido, A.J., Santos, J.F., 1997. Descripción de un método de separación de Rb, Sr, Sm y $\mathrm{Nd}$ en rocas silicatadas para estudios isotópicos. Congr. Ibér. Geoquim. I, 46-55. 
Rock, N.M.S., 1991. Lamprophyres. Blackie, Glasgow, pp. 285.

Suen, C.J., Frey, F.A., 1987. Origins of the mafic and ultramafic rocks in the Ronda Peridotite. Earth Planet. Sci. Lett. 85, $183-202$.

Sun, S.S., McDonough, W.F., 1989. Chemical and isotopic systematics of oceanic basalts; implications for mantle composition and processes. Spec. Publ.-Geol. Soc. Lond. 42, 313-345.

Suriñach, E., Vegas, R., 1988. Lateral inhomogeneities of the Hercynian crust in central Spain. Phys. Earth Planet. Inter. 51, 226-234.

Tejero, R., Ruiz, J., 2002. Thermal and mechanical structure of the central Tberian Peninsula lithosphere. Tectonophysics 350, $49-62$.

Upton, J., Aspen, P., Hinton, W., 2001. Pyroxenite and granulite xenoliths from beneath the Scottish Northern Highlands Terrane: evidence for lower-crust/upper-mantle relationships. Contrib. Mineral. Petrol. 142, 178-198.

Villaseca, C., de la Nuez, J., 1986. Diques camptoníticos en el Sistema Central Español. Estud. Geol. 42, 69-77.

Villaseca, C., López García, J.A., Nuez, J., Ubanell, A.G., 1983. Contribución al estudio de los diques camptoníticos heteromorfos con subfacies ocelares y de diatrema asociadas; Sierra de la Paramera de Avila. Rev. Mater. Procesos Geol. 1, 103-118.

Villaseca, C., Downes, H., Pin, C., Barbero, L., 1999. Nature and composition of the lower continental crust in central Spain and the granulite-granite linkage: inferences from granulitic xenoliths. J. Petrol. 40, $1465-1496$.

Villaseca, C., Orejana, D., Pin, C., López Garcia, J.A., Andonaegui, P., 2004. Le magmatisme basique hercynien et post-hercynien du Système Central Espagnol: essai de caractèrisation des sources manteliques. C. R. Geosci. 336, 877-888.
Vinx, R., Jung, D., 1977. Pargasitic-kaersutitic amphibole from a basanitic diatreme at the Rosenberg, north of Kassel (North Germany). Contrib. Mineral. Petrol. 65, 135-142.

Wells, P.R.A., 1977. Pyroxene thermometry in simple and complex systems. Contrib. Mineral. Petrol. 62, 129-139.

Wilkinson, J.F.G., Stolz, A.J., 1997. Subcalcic clinopyroxenites and associated ultramafic xenoliths in alkali basalt near Glen Innes, northeastern New South Wales, Australia. Contrib. Mineral. Petrol. 127, 272-291.

Wilshire, H.G., Shervais, J.W., 1975. Al-augite and Cr-diopside ultramafic xenoliths in basaltic rocks from western United States. Phys. Chem. Earth 9, 257-272.

Wilson, M., 1989. Igneous Petrogenesis: A Global Tectonic Approach. Unwin Hyman, Boston, pp. 466.

Witt-Eickschen, G., Kramm, U., 1998. Evidence for the multiple stage evolution of the subcontinental lithospheric mantle beneath the Eifel (Germany) from pyroxenite and composite pyroxenite/ peridotite xenoliths. Contrib. Mineral. Petrol. 131, $258-272$.

Wood, B.J., Banno, S., 1973. Garnet-orthopyroxene and orthopyroxene-clinopyroxene relationships in simple and complex systems. Contrib. Mineral. Petrol. 42, 109-124.

$\mathrm{Xu}, \mathrm{Y}$, 2002. Evidence for crustal components in the mantle and constraints on crustal recycling mechanisms: pyroxenite xenoliths from Hannuoba, North China. Chem. Geol. 182, $301-322$.

Ziegler, P.A., 1993. Late Palaeozoic-early Mesozoic plate reorganization: evolution and demise of the Variscan fold belt. In: Von Raumer, J.F., Neubauer, F. (Eds.), Pre-Mesozoic Geology in the Alps. Springer-Verlag, Berlin, pp. 203-216. 